\title{
The Influence of Interpersonal Communication on Relationship Management in Banks in South-East Nigeria
}

\author{
ONWUKA, NWABUAKU ARISA Ph.D OKOLO AMAKA NWAKEGO Ph.D
}

\begin{abstract}
Today's global market is characterized by numerous changes like the 2008 global economic crisis that led to the exit of many banks across the world, cut-throat competition and customers' changing demands among others, causing organizations to rethink and remodel business strategies to ensure competitive advantage. Relationship management, a PR tool has been identified as one of the new business strategies employed by organizations for building sustainable relationships with their various publics. The Excellence Theory of public relations which provides the theoretical background for this study explains that an organization can only be deemed to have attained organizational effectiveness when it is able to establish a sustainable relationship between the organization and the various publics on whom its success or failure depends. What the excellence theory advocates is now popularly referred to as relationship management. A major concern for public relations practitioners therefore has been how to develop and maintain long lasting relationships between organizations and their different publics.The overall purpose of this study therefore, was to investigate the extent to which interpersonal communication influences relationship management in Nigerian banks and the realization of their organizational objectives. The study adopted the use of both qualitative (in-depth interview) and quantitative (survey) approaches. The questionnaire and in-depth interview schedule were the instruments for data collection. The questionnaires were administered to 400 customers drawn from 15 selected banks in South Eastern Nigeria. An in-depth interview was also conducted among 15 selected employees of these banks. The employees were senior officers who interfaced daily with customers, like branch service or operation managers, relationship managers, and heads of customer service. Quantitative data generated as well as formulated hypotheses were tested using Pearson's correlation analysis and chi square, while qualitative data was analyzed using thematic analysis. These were done with the aid of the Statistical Package for Social Sciences (SPSS) and NVIVO. The study established that relationship between banks and their customers is still interpersonal, even in this era of mediated computer and internet banking services, and that interpersonal communication dominates as the most preferred and most popular communication strategy in these banks. Finally, the study demonstrated that interpersonal communication is still very relevant in building and maintenance of sustainable relationships between banks and their customers, and that social media has not after all displaced, but rather complements it. This suggests that this study has answered the excellent question - 'how, why and to what extent does communication, and in the context of this study, interpersonal communication in the Nigerian banking environment, contribute to the achievement of organizational objectives?'
\end{abstract}

DOI: $10.7176 / \mathrm{IAGS} / 75-04$

Publication date: August $31^{\text {st }} 2019$

\section{Introduction}

The difficulty in attracting and retaining customers in today's service industries is increasingly compelling organizations to employ relationship management strategies. In such a competitive environment, it is the friendly customer relations that can retain previous customers and probably attract new ones. Arguably, improved customer relations have the potential of improving profitability and competitiveness of organizations. According to the Excellence theory of Public Relations, an organization can only be deemed to have attained organizational effectiveness when it is able to establish a sustainable relationship with its various publics on whom its success or failure depends. Relationship management is thus a Public Relations tool for building sustainable relationships between an organization and its publics through relationship maintenance strategies that involve the employment of effective communication strategies among others. Tomlinson (2000, p.178) defined the relationship management concept as "the development, maintenance, growth, and nurturing of mutually beneficial relationships between organizations and their significant publics". It is a strategy employed by organizations, especially service organizations, in which a continuous level of engagement is maintained between an organization and its publics. In the view of relationship management, a customer is a valuable asset with a value that should be created in the future to increase the frequency and amount of the purchase and use of services.

The core components of relationship management include communication, trust and credibility, involvement and commitment, reciprocity, openness, mutual satisfaction, among others, Ledingham and Brunning (1998, p.63). According to Ledingham and Brunning, 'programmes developed around these dimensions can engender loyalty toward an organization among key publics'. Communication has been identified as a key strategy in organizations public relations' effort designed to achieve organizational objectives. The role of communication, especially interpersonal communication, can take customers away from service 
organizations such as banks or help them to get closer to them. It then becomes necessary given the competitive nature of the banking industry in Nigeria to appraise the place of interpersonal communication in achieving sustainable relationships between banks and their various publics. Walton some decades ago (1969, p.109) emphasized that "the dynamics of an organization can be best understood by understanding its systems of communication". Since most banks in Nigeria, due to competition and uncertainty of the banking environment, have embraced the relationship management concept (Adiele and Gabriel, 2013), this study, investigates the dominant communication strategies used by these banks in enhancing bank-customer relationships as well as determine the extent to which the interpersonal communication employed enhances relationships in these banks.

\section{Background of Study}

Lately in Nigeria, a radical revolution in terms of customer relationship is increasingly occurring in the banking sector of the economy. The Nigerian market is gradually evolving as a highly competitive market, most especially with the reformation that led to the re-capitalization of her financial institutions (the banking sector) from 89 legally operating banks to 25 consolidated banks by the Central Bank of Nigeria (CBN) in 2004 and presently to 21 banks in 2011 (see table One below). The Nigerian banking sector has witnessed many trends in the recent decades in the course of its development. These include competition, bank failure, the CBN reformation, earlier and recent management philosophies among others. The somewhat 'unhealthy' competition that existed in the banking market, and which was generated by the relative ease of entry of banks into the market as a result of low capital base requirement necessitated some banks going into speculative activities and non-banking businesses which are not related to core banking functions. According to Adeyemi (2007), this constituted a high risk to the health of the banking system and the result was the failure of some of the banks to meet up with their financial obligations. The exposure of some weaknesses of even some seemingly reliable banks, as well as the liquidation of the weakest among them seemed to have aroused fear and uncertainty about the banks' integrity among bank customers. Lemo (2005) noted that the Nigerian banking system was characterized by generally small-sized banks with very high overhead costs, low capital base averaging less than $\$ 10$ million or N1.4 billion, and heavy reliance on government patronage (with $20 \%$ of industry deposits from government sources). There was therefore need for the $\mathrm{CBN}$ banking reforms which trimmed down the number of banks from 89 to 25 in 2010 and further to 21 in 2011 . The reforms took the form of a recapitalization policy that raised the minimum capital requirement of banks from N2billion to N25 billion, with the result that those banks that were not able to meet up with the minimum requirement either wound up, merged with others, or were acquired by financially stronger banks. This seemed to usher in the era of competition in the banking industry and each bank had to look for better strategies for survival.

\section{The Nigerian Banking Environment}

Earlier management philosophies in Nigerian banks as financial institutions appeared to have been based mainly on transactional marketing philosophies. According to Fagbemi and Olowokudeju (2011), early bank marketers believed that their marketing objectives were met at the point of customer acquisition. This corroborates the assertion of Sheth and Parvatiyar (2001), that as customers were available in abundance, early marketers behaved passively with their customers as they primarily focused on maximizing their profits (transaction-based marketing). It would appear that during this era, service standards were set by the banks which saw themselves as kings, while the customers were seen as the favored subjects. Banking policies and concerns seemed to have included little or no customer interests. There was a seeming monopoly of the market by the big old banks, and bank customers were at their mercy, as there appeared to be no form of competition at all. Customers walked in on their own without being prospected, and so had to accept whatever experience they were subjected to, as they seemed to have no choice.

However, according to Gronross (2000), marketing as a field of study and practice went through a reconceptualization in its orientation from transactions to relationships. Sheth, et al (2001) posited that there was a growing recognition that in service marketing, the objective should not only be to attract, but also to keep and maintain the customer, that is to develop a long-term relationship with them. Richheld and Sasser (1990) estimated that the retention of an additional $5 \%$ of customers can increase profit by nearly $100 \%$. This therefore makes maintenance of the relationships between banks and their customers arguably a cost-effective marketing, and this has become a key aspect of most firms' business strategy, prompting extensive deployment of customer relationship management (CRM) systems (Kim, et al., 2003).

The CBN banking reformation made the Nigerian banking environment more volatile, sophisticated and dynamic (Adeyemi, 2007). Today, with the emergence of competition in the banking industry at cut-throat level, and customer demands appearing to increase, even as service improves, the banking environment has become so volatile that the banker-customer relationship appears to be no more symbiotic but tilting in favour of the customer. Bank managements appear to have come to realize that there is only one person who is capable of firing everybody in the organization, from the managing director at the center to the cleaner at the service point, 
and that is the customer. This the customer can do by simply taking his money to another bank - the competitor. With this realization, the position of the customer appears to have taken a dramatic turn, and assumed an exalted level. The customer has come to be known as the 'king', the 'boss' and the 'employer'. The need to satisfy the customer thus became inevitable to ensure survival as customer satisfaction is expected to ensure customer loyalty to the brand and improve business performance. In the bid to win the acceptance of the customer as a reliable brand, each bank appears to be looking for relational maintenance strategies that will lead to sustainable customer relationships, in order to remain relevant. The management pendulum thus tilted towards the evolution of relationship building and management. The extent to which the goals of relationship management have been achieved as against the traditional marketing concept, as well as the central role of communication, specifically, interpersonal communication, in achieving these goals, are all part of this investigation.

The relationship era led to the emergence of two categories of banks in Nigeria, popularly labeled as the 'New' and 'Old Generation' banks, probably because of the differences in their characteristics and service delivery methods. While the old generation banks are mostly the premier banks in Nigeria that were formerly characterized by old processes and outdated technology, but seem to have been suddenly and consciously transforming themselves through re-engineering of people and processes into modern banks, the new generation banks on the other hand are the modern banks that sprang up to challenge and appear to overtake the big old banks with their 'new wave' banking practices. The employees of the new generation banks wear very smart appearances and appear assertive, compared to the old generation bank employees. Their banking environments were cozier than those of the old generation banks and their service delivery packaging faster, more customerfriendly but most importantly geared towards an upward mobile use of various forms of communication strategies. Some of the old generation banks in Nigeria have operated for many years, while the new generation banks are very much younger. Suffice it to say that these banks, whether old or new, appear to have embraced the relationship management concept as part of their PR efforts to increase customer base. As Adiele and Gabriel (2013) noted, 'these days, banks have realized that customer relationship is a very important factor for their success'. While the modern banks seem to have aggressively deployed this strategy, this work comparatively appraises the different communication strategies employed by these banks and the interface between interpersonal communication as used in these banks and relationship management. Below is the list of current banks in Nigeria, categorized for the purpose of this study, into old and new generation banks, together with their individual slogans that drive their businesses.

Table One:

List of Current Banks in Nigeria

\begin{tabular}{|r|l|l|}
\hline S/N & CURRENT BANKS IN NIGERIA & SLOGANS \\
\hline \multicolumn{2}{|c|}{ OLD GENERATION BANKS } & Truly the First \\
\hline 1 & First Bank of Nigeria Limited & Doing Things right \\
\hline 2 & Mainstreet Bank Limited (formerly Afribank) & Where You Matter \\
\hline 3 & Savannah Bank Nig. Ltd & Big, Strong, Reliable \\
\hline 4 & Union Bank of Nigeria (owned by African Alliance Consortium) & Africa's Global Bank \\
\hline 5 & United Bank for Africa Limited & The City Never Sleeps \\
\hline 6 & CitiBank & We Keep Our Word \\
\hline 7 & Fidelity Bank Plc & Here for Good \\
\hline 8 & Standard Chartered Bank Plc. & Wouldn't You Rather Bank With Us? \\
\hline 9 & Guarantee Trust Bank Plc. & Convenience and Reliability \\
\hline 10 & Keystone Bank Limited (formerly Bank PHB) & Speed, Service, Security \\
\hline 11 & Access Bank (acquired Intercontinental Bank) & Your Bank \\
\hline 12 & Diamond Bank Plc. & Expanding Your World \\
\hline 13 & Skye Bank & Moving Forward \\
\hline 14 & Stanbic IBTC Bank Nigeria Limited & One Bigger, Better \\
\hline 15 & Enterprise Bank Limited (formerly Spring Bank) & My Bank and I \\
\hline 16 & First City Monument Bank Plc. (FCMB) & The One Customer Bank \\
\hline 17 & Sterling Bank (acquired Equatorial Trust Bank) & In Your Best Interest \\
\hline 18 & Zenith Bank Plc. & Succeeding Together \\
\hline 19 & Unity Bank Plc. & Together to Greater Heights \\
\hline 20 & Wema Bank Plc. & The Pan African Bank \\
\hline 21 & Eco bank Nigeria (acquired Oceanic Bank) &
\end{tabular}

Source: http://www.cenbanjk.org/Supervision/Inst-DM.asp 


\section{Statement of Research Problem}

So much emphasis has been laid on the relationship management concept, a multi component construct that uses the mechanism of trust and credibility, involvement and commitment, service excellence, and communication among others to achieve its goals, as a major strategy for achieving customer loyalty. Quite a number of studies have been carried out in this area in advanced countries like the USA, United Kingdom, Sweden and the like on relationship management (Rootman 2011), and complemented by few studies in Nigeria. However, most studies reviewed, especially in the banking sector, concentrated on transactional marketing and relationship marketing efforts, relating relationship management with brand loyalty, increased profits, and customer satisfaction and retention. While most of the above components and their roles on relationship management were studied, there was little or no detailed reference to communication. The few studies available for review in Nigeria concentrated on customer relationship management, which is a marketing research, with only a little attention devoted to communication. Nonetheless, we often hear about communication gap being the cause of breakdown in relationships or misunderstanding among parties who seek mutual understanding and acceptance. For instance, Mohegan (2010) explains that even when partners speak the same language, they don't always understand what each other is saying, and so a little conversation can turn into an area of conflict, particularly if it involves a sensitive subject. This was corroborated by Karten (2002) when she explained that 'both parties to miscommunication too easily forget that although they are using the same words, they speak different languages' (p. 65).

However, the introduction of the social media has radically changed the way we communicate and relate at various levels. This has also found its way into banking operations and services; and might have displaced, replaced, or complemented existing communication strategies being used. Since Nigerian banks appear to have seen the need to shift emphasis from the transactional to relational concept in their business activities and now seem to be establishing closer and stronger

relationships with their customers than before (Ogbadu and Usman, 2012), and given the relevance of communication and the interface between traditional media, new media and business relationships, there is the need to examine the place of interpersonal communication, among other communication strategies in relationship management in Nigerian banks, as well as its contribution or otherwise to the achievement of relationship management goals in these banks. The inherent issues here are, with the advent of social media in banking services, has it displaced the traditional interpersonal communication in banks as the main communication strategy, or does interpersonal communication still appear to be the dominant communication strategy used? If interpersonal communication still has a place in relationship maintenance, it is pertinent to find out the most popular and most preferred pattern by customers, as well as how this communication strategy affects bank-customer relationships.

\section{Purpose of Study}

This study seeks therefore to explore the role of interpersonal communication, which involves interaction between two or more people, using both verbal and non-verbal cues, in building and sustaining relationships between these banks and their customers.

\section{Objectives of Study}

The general objective of the study is to determine how interpersonal communication affects relationship building and maintenance in Nigerian banks. The following specific objectives are:

1. To determine the different communication strategies used by banks in achieving relationship management goals.

2. To ascertain the place of interpersonal communication among these communication strategies in relationship management in Nigerian banks.

3. To ascertain the different types of interpersonal communication patterns used by banks in managing relationships.

4. To examine the extent to which the relationship management concept contributes to the realization of banks' objectives.

5. To establish the extent to which interpersonal communication influences relationship management in banks and the realization of their organizational objectives.

\section{Research Questions}

1. What are the various communication strategies used by banks in relationship management?

2. What is the place of interpersonal communication in relationship management in Nigerian banks?

3. What are the different patterns of interpersonal communication used by the banks in managing relationships?

4. To what extent does the relationship management concept contribute to the realization of banks' organizational objectives? 
5. To what extent does interpersonal communication influence relationship management in banks and the realization of organizational objectives?

\section{Scope of Study}

Relationship management is a partnership-oriented and multi-component approach that seeks to create mutually beneficial relationships between organizations, especially service organizations, and clients through the mechanism of trust, commitment, and communication among others. Therefore this study is limited to measuring the influence of the communication component on relationship management success in Nigerian banks.

This study was purposefully delimited to the commercial banks in the South Eastern region of Nigeria, totaling 25. The physical setting for the study was made up of all the five states of South Eastern Nigeria, where commercial banks are located, vis-à-vis, Abia, Anambra, Ebonyi, Enugu, and Imo. This is because all the banks operating in the South East could be found in any other part of the country. There is therefore the belief that the findings of this study in the South East could be used to generalize to other commercial banks in any part of the country. The target audience is limited to customers of the sampled commercial bank branches in the focal area, as well as employees of these banks who engage in relationship management.

\section{Significance of study}

Communication in relationship management might appear a latent component, but in building and maintaining strong relationships, it is non-the-less, a critical element. This study is important for banks managements, employees, customers, the academia, and even the government.

1. Communication had earlier been identified in literature as a strong component of the relationship management concept. What appeared to be missing was a detailed exploration of its impact on relationship management. This study attempted to bridge this gap by opening a chapter on the communication component of relationship management, emphasizing its contribution to relationship management in service organizations.

2. The study also highlighted the continued relevance of interpersonal communication in service industries in Nigeria, even in this era of digital communication technology.

3. In the same vein, this study is significant for policy formulation because the findings will help both the commercial banks and the Central Bank of Nigeria which is the Apex bank to formulate policies that will create mutual value for all the parties involved in the relationship, i.e., banks and their customers.

4. It is a timely, ground-breaking research in relationship management in Nigerian banks and so serves as a reference point to other researchers.

5. This study is significant to banks because customers are viewed as important elements in organizational performance of banks. When the relationship with customers is properly managed, a bank may have a comparative advantage over others and business performance will be enhanced.

6. It is also significant to bank customers because improved relationships will bring greater satisfaction to them, as they will have access to better and qualitative services from the banks.

7. Employees likewise will realize more the implications of relationship management on business performance, as well enjoy better conditions of service due to better organizational performance.

8. This study contributes to literature because relationship management is an emerging concept in Nigeria and so only few literatures are available in the field. Findings from this study will therefore add to the available literature on the subject in Nigeria.

9. It is also relevant for other service organizations outside banking that could be attracted to venture into relationship management.

\section{LITERATURE REVIEW}

\section{The Concept of Relationships}

It is important to discuss the concept of relationships in order to understand its management. A number of fields other than public relations also use relationships as a central concept. Interpersonal relations, family relations, group dynamics, labour management relations, councilor-client psychotherapy relations, organizational studies, and international relations are but a few of the many domains of theory and practice based on understanding and observation of relationships, (Ledingham \& Bruning, 2000 p. 7).

For the purpose of this study, relationship is described as the way in which an organization's employees are connected with or involve each other as well as the various publics of the organization. Relationships between people or groups can be likened to physical connections. Having a good relationship is like being joined to the other person or group, and ending a relationship is like breaking this connect. Ledingham and Bruning (1998, p.62) defined organization-public relationships as "The state that exists between an organization and its key publics that provides economic, social, political, and/or cultural benefits to all parties involved, and is characterized by mutual positive regard". This definition of relationships appears to be quite narrow in that it 
excludes negative relationships that can develop. Hon and Grunig (1999) therefore expanded this by explaining that an organization-public relationship occurs when there are organizational behaviors that have consequences on publics or when publics' behaviors have consequences on an organization.

\section{Types of Relationships}

Grunig, Grunig, and Dozier (2002) identified two types of interpersonal relationships that can be used to assess the relationship between an organization and a public. These are exchange and communal relationships.

In an exchange relationship, one party gives benefits to the other only because the other has provided benefits in the past or is expected to do so in the future, or a party is willing to give benefits to the other because it expects to receive benefits of comparable value from the other. In essence, a party that receives benefits incurs an obligation or debt to return the favor. Exchange is the essence of marketing relationships between organizations and customers and is the central concept of marketing theory. Banks' relationships with their customers are based on the principle of exchange. They lend money to the public, for instance, because they expect interest payment. Similarly, customers save their money in the bank because they too expect returns on investment in the form of dividends or interest payment, as well as safety of their money.

However, an exchange relationship usually is not enough for a public. Publics expect organizations to do things for the community and their stakeholders for which organizations sometimes get little or nothing in return-at least in the short run. This understanding probably gave rise to the development of communal relationship. In a communal relationship, in contrast, parties are willing to provide benefits to the other because they are concerned for the welfare of the other, even when they believe they might not get anything in return. The role of public relations is to convince management that it also needs communal relationships with publics such as employees, customers in case of banks, the community, and the media, among others. Public relations professionals add value to an organization when they develop communal relationships with all publics affected by organizational behaviors, not just those who give the organization something in return. Communal relationships are important if organizations are to be socially responsible and to add value to society as well as to client organizations. Banks do engage in social responsibility activities like buying operational vehicles for the police, building classroom blocks for schools, among others just to improve communal relationships. The management of these interpersonal relationships through interpersonal communication in banks forms the basis of this study.

However, Grunig and Dozier (2002) noted that relationships often begin as exchanges and then develop into communal relationships as they mature. According to, Grunig and Dozier sometimes, public relations professionals may need to build a communal relationship with a public before an exchange can occur. Thus, the success of the public relations management function may de

Demonstrating Openness (of thoughts and feelings among parties involved), also referred to as direct discussion and disclosure, relates to the extent that parties are ready to involve in self-disclosure. Being open helps to reduce uncertainties and ambiguities in interactions and contributes to the growth and strength of organization/public relationships as explained by the Uncertainty Reduction Theory, which supports this study.

Providing Assurance (statements that imply a future), involves the demonstration of commitment and loyalty to the relationship as well as attempts by each party to assure the other that they and their concerns do matter. This strategy also might involve attempts by the parties in the relationship to demonstrate to each other that they are committed to maintaining the relationship. Stafford and Canary (1991, p. 217-242), observe that reassurance is communicated by confessing our continued commitment to the other party and implementing our commitments, by investing time, energy, and self in the relationship. Banks, for instance, are expected to be committed to fulfilling the service promises they make to their customers and when they do, such is expected to engender trust and loyalty to the brand. A gesture as simple as remembering a birthday, may constitute a reassurance in a relationship.

Integrating into Social Networks or use of common associations to keep the relationship going happens when members of a primary relationship, who have an exclusive relationship with one another, are connected to a larger social circle. Organizations do build networks or coalitions with the same groups that their publics do, such as environmentalists, unions, or community groups.

\section{Relationship Outcomes}

The concept of relationship outcomes was first introduced by Huang (1997) to public relations. Huang argues that the quality of organization-public relationships resulting from public relations practice can be represented by trust, control mutuality, relational commitment, and relational satisfaction. focusing on relationship outcomes and how to measure them. Broom, Casey, and Ritchey (1997) and Huang (1997), also confirmed these four as both outcomes and good indicators of successful relationships.

According to Grunig and Huang (2000), organization-public relationships are successful "to the degree that the organization and public trust one another, agree on who has rightful power to influence, experience 
satisfaction with each other, and commit oneself to one another" (p. 42-43). Findings from this study will reveal whether banks have been able to manage their relationship with customers such that customers trust the bank, and are satisfied to the extent that they have become loyal customers.

\section{Relationship Management in Public Relations Practice}

According to the relationship management perspective in public relations, 'an organization's livelihood is affected by its ability to develop mutually satisfying relationships' (Ledingham, 2002 p.181). A public's opinions about the relationship it has with an organization affect its satisfaction with the organization (Bruning and Ledingham, 1999), its intentions (Bruning and Ralston, 2001), and its actions (Bruning, 2002). Ledingham and Bruning (1998) defined organization-public relationships as 'The state that exists between an organization and its key publics that provides economic, social, political, and/or cultural benefits to all parties involved, and is characterized by mutual positive regard' (p. 62).

The relational perspective of public relations (PR) evolved as a result of the search by scholars for the exact and un-questionable value of PR to an organization. For many years, the question of where PR fits into the range of business activities in general and its relationship to organizational management and effectiveness in particular, seems to have occupied the minds of practitioners and academics alike. For instance, there were debates on the relationship existing between PR and marketing. Some described the relationship as fractious (Gregory, 2006a), adversarial (Theaker, 2006), and a power struggle (Oliver, 2006). While a total separation of the duties of PR and marketing were perceived to be difficult, Hallan (1992) as cited in Grunig and Grunig (1998), proposed six possible arrangements for the co-existence of both in an organization. These were: celibate - existence of either, co-existence - operating separately, combative - operating at odds, co-optive - one function usurping the other, coordinated - both working together, but independently, and lastly, combined - where the two share a single unit.

These debates came up probably because it was not quite obvious what the exact contribution of PR to organizational effectiveness was. Ledingham and Bruning (2000a) in this regard, suggested that the emergence of relationship management as a paradigm for public relations scholarship and practice 'calls into question the essence of public relations. i.e., what it is and what it does or should do, its function and value within the organizational structure and the greater society, as well as the benefits generated not only for sponsoring organizations but also for the publics those organizations serve and the societies in which they exist'. (P. xiii)

Before the relationship management era, scholars, public relations professionals, and counselors defined public relations as simply "the management of communications" ( Grunig \& Hunt, 1984, p.6). Recently, however, more and more scholars and practitioners began to recognize that mediated communication is not an end. In other words, mediated communication may or may not contribute to organizational effectiveness. As Lindenmann (1999) stated, "more importantly, public relations practitioners have begun to recognize that messages are not just distributed through press releases to the media or through company magazines and newsletters mailed to employees and customers, but ultimately are transmitted to various publics by behavior of the organization, by the quality of the products and services they deliver, and the gap between promises and action" (p. 19). This is interpersonal communication, expressed through verbal and non-verbal cues, and leading to the development of interpersonal relationships.

The relational perspective that relationship management encompasses holds that public relations is 'the management function that establishes and maintains mutually beneficial relationships between an organization and the publics on whom its success or failure depends, and this is expanded by the Excellence Theory of public relations (Grunig, 1984). The Excellence Theory specifies how PR makes organizations more effective, how it is organized and managed in order to contribute most to organizational effectiveness, the conditions in an organization and their environments that make organizations more effective, as well as how the monetary value of PR can be determined. It explained that the value of PR lies in organization-publics relations, and argues that by helping organizations build relationships and by resolving conflicts between the organization and its strategic publics, PR department contributes to organizational effectiveness. The extent to which the PR department in banks, where such exists or its representation, where it does not, has been able to contribute to banks' effectiveness by building and fostering good and long-term relationships between the banks and their customers, forms the main focus of this study.

Bosch, Tait, and Venter (2006) refer to communication as the transfer of information through symbols that ensure the exchange and sharing of ideas, attitudes, opinions and facts. Van Riel and Fombrun (2007) perceive communication as the lifeblood of an organization. That means that if we could somehow remove communication flows from an organization, we might not have an organization. They further explained that a firm's communication system consists of the media used to communicate to internal and external stakeholders.

\section{Forms/Types of Communication}

Banks communicate through various means and forms like Interpersonal communication or one-on-one 
interaction, phone calls, letters, Mass media, websites on internets, the social media, promotions, public relations and account statements, among others.

Relationship Management is based on creating a mutually beneficial exchange between business partners, and this often requires personal communication with the customer. Herbst (1999) posit that the application of successful relationship management strategy in practice is based on the adherence to the principles of effective communication. According to Herbst, through proper implementation of the communication principles, the relationship marketing practitioner will, in the new millennium, ensure survival in a tremendously competitive environment.

Word of mouth (Kotler, Armstrong, and Tait 2010) and marketing communication (Elliott 2009), are also regarded as methods of communication to and from clients. Word of mouth communication refers to the referrals a firm receives because of personal communication about its products and services between target consumers and neighbours, friends, families and associates (Kotler and Armstrong 2001). Word of mouth comes as a result of good relationships existing between the bank and its customers, wherein customers recommend the bank to their friends and relatives. Rootman (2011) also sees complaint handling procedures as a form of communication used by banks to convey information or interact with their customers. (Complaint handling procedure is the handling and solving of a complaint or grievance of a bank client). Proper complaint handling is a very strong contributor to a sustainable relationship between a bank and its customers.

Communication is not just about sending or receiving information. Its very essence is the sharing of meaning between the sender and the receiver. Lages, Lages, and Lages (2005) assert that the quality of relationship is directly proportional to the quality of communication in an organization. In other words, a successful relationship is a function of the extent to which an organization is able to get its customers understand the information it is passing on to them, whether verbal or non-verbal, while getting the customers appreciate the import of that information, in order to be able to provide useful feedback. According to Gremier and Givinner (2000), rapport or harmonious communication between a firm's employees and its clients lead to increased client loyalty levels and positive word of mouth recommendations. Bank employees, for instance, are expected to communicate at the same level with customers, using simple language, as well as the right choice of words. The use of professional jargons is likely to result in ambiguity in interaction, and this can lead to uncertainty. This, the uncertainty reduction theory of interpersonal communication reviewed in this work tends to address.

\section{Interpersonal Communication}

This is the process by which people exchange information, feelings and meanings through verbal and nonverbal messages. It mostly involves face to face communication and sometimes mediated messages through telephone interaction. Interpersonal communication is described by Sethi and Seth (2009), as 'the procedure by which people swap information, feelings and impart through verbal and non-verbal messages'. This implies that interpersonal communication is not just about what is said - language used- but how it is said, including the nonverbal messages sent through tone of voice, facial expressions, gestures, body language, and dressing. People receive messages from these forms of nonverbal behavior.

Interpersonal communication is also described as the process of exchanging messages between people whose lives influence one another in unique ways in relation to social and cultural norms (2012books.lardbucket.org). This definition highlights the fact that interpersonal communication involves two or more people, that they are interdependent in one way or the other, and that they build a unique bond based on the larger society and cultural context to which they belong. Therefore, a brief or one-off encounter with an unfamiliar person who does not influence the communicator may not be termed interpersonal communication.

The elements of interpersonal communication include the communicator, message, channel, context, noise, and feedback.

\section{Interpersonal Communication Skills}

The above explanation that relationship management often requires personal communication, whether verbal or non-verbal, formal or informal with the customer, makes it imperative that bank proposals should therefore be communicated effectively and appropriately to customers and employees if relationships are to succeed and be sustained. How well we communicate depends on our interpersonal skills. Hargie, O. (2011) explains that people with higher levels of interpersonal skills are better able to adapt to stress, have greater satisfaction in relationships, make more friends, and have less depression and anxiety. This suggests that interpersonal skills can have a measurable impact on health and psychology. Interpersonal skills consist of listening skills, problem solving, and question asking skills, among others. Good communication skills among bank employees therefore cannot be over-emphasized.

The marketing team for instance, goes out daily to sell the bank's products and services to targeted customers, while the service personnel at the touch points deliver the service promise to the customers, all through interaction. The customer has unique interest, needs, attitudes preferences and aversions, issues and 
opportunities, and of course the authority to spend his money on the bank's offerings. The uniqueness of the relationship management orientation is its ability to communicate the company service promises through an effective communication strategy, complete with a two-way dialogue which results into a cordial relationship between the bank and its customers. Therefore, if interaction with the customer is a requisite part of the relationship programme, then bank employees should possess the requisite communication skills to interact appropriately with the customers, capture the right type of information from them, and be able to determine how such information should be used to shape future communication.

Relationship management is designed to develop strong connections with customers by providing them with information directly suited to their needs and interests and by promoting open communication. This approach often results in increased word-of-mouth activity, repeat business and willingness on the customer's part to volunteer information to the organization.

Boone (2001) observes that 'most managers and executives spend a huge portion of their budget on communication bandwidth and hardware without stopping to think about their own communication skills or the quality of communication in their organizations. She continues that "the act of communication is as important as the technologies we use to connect to each other" Even though a lot of technologies have been put in place to enhance service delivery, studies have proved that technology cannot replace the human element in service delivery and customer satisfaction as was earlier pointed out by Ledingham and Brunning, (2000). In Patricia Sorce's (2000a) survey, customers' responses showed that they did not like it when their calls were taken by answering machines. Similarly, experience has shown that in Nigerian banks, a lot of customers, especially the older generation, are averse to using the alternative delivery channel - the Automated Teller Machine (ATM) because they want to see and interact with people - human beings. They want to hear human voices, see human faces and feel human actions, not machines'.

The one to one marketing concept of relationship management depends very much on good interpersonal communication skills. Taking a cue from Gremier and Givinner (2000), the success of every relationship management strategy is therefore likely to be a function of adequate interpersonal skills of the marketers or organization's employees who interact with the customers. This is also supported by Sethi and Seth (2009), who posit that decent interpersonal skills support intimate relationship, counseling, selling, and conflict management.

Emotional intelligence, self-awareness, empathy, and self-motivation are all factors that may affect the effectiveness of interpersonal communication, which in turns helps in building and maintaining good relationships. Some of these factors are in turn largely dependent on the knowledgeability of the communicator. A good knowledge of the banks policies, products and services, processes and procedures by the employees will, for instance, foster a good relationship between them and the customers as this will help the employees relate well with the customers and serve them better. In the same vein, a good knowledge and understanding of the banks intentions for the customer, policies and activities as they affect customers' interests may, if effectively communicated to them, eliminate conflicts and suspicion of the banks actions and make for good understanding between the two parties.

In the service sector, Thomson and McHugh (2002) note that an increase in the tacit knowledge of employees leads to improved competitiveness for the firm. Tacit knowledge is said to be the ability to be practical and action-oriented with regard to a firm's products and services (Greenberg and Baron 2000), and comprises their insights, intuitions, and emotions. Conflict management and resolution as well as negotiations skills are equally interpersonal communication imperatives for the bank employees if good relationships are to be built and maintained with customers. This is because in the work place, one who is good in interpersonal communication can relate to and work with a wide variety of people, negotiate differences, handle conflicts, make requests effectively and receive information objectively', NUS (2010).

Therefore, since communication has been identified as the process that leads to relationships, it is important to investigate whether bank employees possess the requisite communications skills to interact with their teeming customers in order to foster close relationships between them and the bank. These skills will enable them achieve interpersonal communication competence, which is the ability to communicate effectively and appropriately. The study therefore looks at bank employees' tone of the voice, choice of words, and listening skills among others, when communicating with customers, and how these affect the achievement of relationship management goals.

\section{Relationship Management Practice in the Nigerian Banking Sector}

The banking sector is becoming increasingly competitive around the world. This is because the sector operates in a very dynamic marketing environment, resulting from rapid changes in technology; consumer tastes, economic and social forces. The world-wide influx in the financial markets has affected the conditions for operations in the Nigerian markets as well, and banks have experienced a radical change during the last decade (Fagbemi and Olowokudeju, 2011). Furthermore, Adedeye (2013), observed that the core and actual products offered to customers by banks could be considered reasonably homogeneous. Adedeye also sees the purpose of a business 
as mainly to create customers, and he stressed the importance of keeping those same customers and growing the depth of their relationships with the business. The banking industry in Nigeria is undergoing a period of dynamic change. For a long time, financial service providers had presumed that their operations were customercentric, simply because they had customers and were able to generate profits. However, in the current era of hyper competition, a very slight difference exists in the services provided by the major players, because services are homogeneous, and the boundary between the offerings of major players in the industry are becoming increasingly blurred (Fagbemi, et al 2011). Consequently, there is an increased need for banks to differentiate themselves from the look-alike offerings of competitors. One way to achieve this is to develop longer-term relationships with their key customers. The strong rivalry and customer sophistication, which characterize today's business environment, has thus resulted in the building of stronger firm-customer relationships (Ndubisi, 2007), popularly referred to as organization-public relationship (OPR).

Banks before now appeared to have taken relationships for granted probably because there was limited competition. Few bank seemed to care much about customer satisfaction or concerns. Customers on their own part appeared to be ignorant of their rights as customers. They therefore were taken for granted and so banks appeared to see less need for relationship cultivation and maintenance. Today, customers appear to have become more sophisticated, and because competition has set in among the banking sector, they have more choices of banks to patronize, and have become aware of their rights as customers. Banks therefore had no better choice but to tilt the relationship scale in favour of the customer. This gave rise to the development of relationship management practice in Nigerian banks. In order to effectively adapt to the changing environment, achieve set goals and objectives, as well as improve organizational effectiveness, Nigerian banks joined the global business environment as stated by Eisingerich and Bell, (2006) to design different marketing strategies; and policies have been focused on the process of service delivery, rather than the service itself (Fagbemi, et al, 2011).

There are many categories of customers whose patronage is sought by banks. These include retail customers, corporate, high net-worth that is those customers whose assets far exceed their liabilities in the books of the banks, the public (government) sector and the institutional customers, such as the oil companies. Before now, customer relationship management was focused on the high net-worth customers alone, as expressed in the 80/20 report above. Today, it appears that the CBN banking reforms discussed earlier has resulted in the mass retail customers' funds though without high volumes, largely forming the deposit base of the banks in Nigeria. So attention appears to have been extended to the mass customers. As a result, all customers are now seen as relationship customers, and relationship management is therefore designed for all categories of customers. Our study will therefore involve a blend of all of them, including the bank employees, referred to as the bank's internal customers, who interact with the customers in the course of banking business like the service managers, relationship managers and other senior bank officers.

It becomes necessary, therefore to investigate how bank employees who engage in relationship management use interpersonal communication in their day to day interaction with the customers and how this affects achievement of relationship management goals and outcomes.

With the dawn of the relationship era in banks, came the relationship marketing approach. Relationship Marketing precedes relationship management, and is used by bank marketers or relationship managers to build and maintain relationships with their customers during their marketing drives. This is a one-to-one marketing concept in which markers are expected to meet customers one-on-one and sell the banks products and services to them, and is achieved through personal interaction which involves a good knowledge and use of interpersonal communication skills. While relationship management is a partnership and multi-component construct that seeks to create mutually beneficial relationships between organizations, especially service oriented organization's like banks, and their clients through the mechanism of communication, commitment, and trust, service excellence, service loyalty, among others, Walsh, Gilmore and Carson (2004: 469) define relationship marketing as the activities implemented by banks in order to attract, interact with, and retain 'more profitable' clients. This suggests that relationship marketing is operates on the Pareto principle, is targeted to the high net-worth customers, and is more appropriate in service industries, especially banks. The empirical review will thus include research studies on relationship marketing.

However, there appears to be a synergy between relationship management and relationship marketing. Both have the building and maintenance of sustainable and mutually beneficial relationships between the bank and its customers as their primary goals. Both also have interpersonal communication at the core because they engage mostly in one on one interaction.

The differences between relationship management and relationship marketing are few. Relationship marketing is a marketing technique employed by bank marketers who lunch out daily to sell the bank's products and services to targeted customers. It is targeted mostly at the bank's high net-worth customers and applies the 80/20 principle of Pareto, while relationship management is a PR strategy used by the service personnel at the touch points to deliver the bank's service promises to all categories of customers through personal interaction. Table three below compares and contrasts relationship management and relationship marketing: 
Customer relationship management (CRM) is the technical tool of relationship management and marketing in achieving relationship goals. It involves developing a robust technology that captures customer information in a data base in such a way that recognizes changing trends, analyzes data on customer satisfaction, and makes use of information that states customer preferences, while obtaining the feedback necessary to fully understand the customers and respond to negative customer satisfaction information. Sin, et al. (2005) viewed CRM as 'a comprehensive strategy and process that enables an organization to identify, acquire, return, and nurture profitable customers by building and maintaining long term relationships with them.'. It includes all marketing activities which are designed to establish, develop, maintain, and sustain successful relationships with the target customers. CRM identifies the present and future markets, selects the markets to serve, and identifies the progress of existing and new services. It involves reading the customer's changing needs and creating services to satisfy these needs (Olowokudejo, et al 2011). Most of the studies conducted in Nigeria on relationship management focused on CRM. Adeyeye, et al (2013) in their study, pointed out that more and more executives and managers have realized that CRM is not just the responsibility of the marketing department, or customer services department, but that it is a fundamental business strategy carried out within the whole organization, spanning different business functions.

Adopting CRM effectively tends to give an organization distinctive or comparative advantage over competitors, because it enables them to communicate effectively with the customers and know what they need and want. It also highlights the reasons why some continue to patronize an organization, while others leave, and the strategies to use to manage their customer relationships effectively. When long-term relationships exist between a bank and its customers, the distance between them becomes shorter, and the bank benefits from repeat purchase and goodwill of the customer (Jackson, 1985; Groonroos, 1990).

\section{Empirical Studies}

Scholars have connected relationship evaluations with customer retention, employee retention, and rapid recoveries from crises (Ledingham, Bruning, and Wilson, 1999; Wilson, 2000; Yangand Mallabo, 2003). Presented below are the empirical studies reviewed in this work:

Mooreale, (2000) as cited in Hybels and Weaver II (2004), conducted a survey on communication skills among American workers about their educational preparation for the work force. The workers rated the ability to communicate and think critically as being more important than computer or other job specific skills. According to Hybels et al (2004), the result of this national survey of 1015 adult workers showed that 87 percent of the respondents rated communication skills as being very important.

Even though Mooreale's study is not on relationship management, it focuses on employees' perception and rating of communication skills in relation to workforce effectiveness. As earlier stated in the conceptual review, the employees are the internal customers of any organization, and relationship management success appears to be a function of the communication outcomes of the employees who interact daily with the organization's publics. Since communication is said to be the process that leads to relationships, this study sought to find out if bank employees who interact daily with the customers that visit the service points or relate with the relationship managers/marketers who visit them at their shops, possess the requisite interpersonal communication skills to drive the relationship management orientation to a success in Nigerian banks.

Online dialog and relationships were examined through the engagement of activist publics. Taylor, Kent and White (2001) examined 100 websites created by activist organizations and discovered that while most of the websites were designed for two-way communication, ultimately they did not utilize or engage in two-way communication. Furthermore, they found that organizations focused more attention on non-media publics, such as their member publics, or those who were involved within the organization, than they did on the media, social or traditional. It could therefore be inferred from these findings that the focus on non-media publics by organizations would generate the use of non-mediated communication, which this study is investigating.

Patricia Sorce (2002) examined customer communication preferences in driving relationship marketing to a success in the US. An exploratory study of 160 adults was conducted to determine their preferences for common relationship marketing tactics such as receiving mail from businesses they patronized, getting e-mail notices of sales, joining frequent buyer programs, and use of customer service phone lines. The purpose of the research was to understand the impact of relationship marketing strategies on the demand for customized communication through printing.

First, the foundations of relationship marketing strategy were presented. In particular, the central role of loyalty was discussed as the mediating factor in building relationships with customers. Using the concepts of brand equity, value equity and retention equity as presented in the Customer Equity model designed by Rust, Zeithaml and Lemon, Sorce (2000) argued that to build retention equity common to most relationship marketing programs, marketers need to understand the relationship from the customer's point of view.

The results indicated that catalogs and direct marketing were viewed very favourably by the respondents. Commercial e-mail messages were viewed somewhat less favourably. There was not a high level of interest in 
frequent buyer programs. A factor analysis revealed that this preference combines to form four dimensions representing the different forms of media to communicate with the customer: printed mail, e-mail, telemarketing, and face-to-face service. She therefore submitted that relationship marketing strategies will be successful if customer communication preferences are part of the customer profile database of a firm. This underscores the importance of communication strategies as a dimension of relationship marketing to the success of building lasting relationships with the customer.

Since Source concluded that interaction with the customer is a requisite part of the relationship programme, then it could be argued that it is pertinent for banks to understand how best to obtain information from their customers and utilize such to shape future communication. Leaning on this, therefore, this study investigated whether interpersonal communication is best used by the Nigerian banks to obtain information that will sustain relationships with their customers.

Kent and Taylor (2002) were at the forefront of bringing Public relations' move to the Internet through their discussions of dialogic theory and creating relationships online. Dialogic theory, according to them, refers to dialogical communication as a part of Grunig and Hunt's two-way symmetrical communication. They stated that it is a procedural issue where two-way communication is the process, and dialogue is the product that results from that communication. Kent and Taylor suggested that the web is a great place for fostering dialogic communication.

Similarly, Kent, Taylor, and White (2003) looked at how organizations utilize technology to engage stakeholders. They examined 150 websites of activist publics and watchdog publics. When attempting to solicit information from the web masters there was a return rate of only 16 percent. That lack of response meant that a low number of these websites were engaging publics. The authors suggest that organizations that rely on relationships with their publics need to solicit, consider, and adjust to stakeholder feedback. Therefore they agreed with earlier researchers that it seems that online communication supplements the relationship building process rather than replaces it. This is because relationship building can occur both online and offline and not solely in one place. Since there are still things that cannot be encompassed by the Internet, such as face-to-face communication, they concluded that offline relationships still have a place in public relations. How to successfully manage these off-line relationships through interpersonal communication is the main concern of this research.

Online relationship building was further researched by Jo and Kim (2003). Surveying college students, they reported that the technological advancement of the website does not correlate with a number of favourable attitudes, such as trust, commitment, or satisfaction, toward the website. They advised that organizations must utilize the web to engage publics and not simply rely on the medium of communication to produce a relationship.

Even though the researcher tried to persuade organizations to utilize more of the website than the communication medium, the report of findings from this study confirms that users of websites express dissatisfaction, lack of commitment and trust. The inference here is that the study appears to tilt in favour of offline relationships through communication, which of course, this study is investigating, rather than on-line relationships through the web.

The three studies above by Kent and Taylor, Joe and Kent, Taylor and Whyte seem to focus more on creating on-line relationships than off-line, and encourage organizations not to rely solely on the medium of communication in this present world of technological advancement, where social media appears to be the new song in building and maintaining relationships. Based on this therefore, the current research sought to explore whether interpersonal communication still occupies an important place in the building and sustenance of bankercustomer relationships in banks in Nigerian banks.

Ahiauzu (2006), in his study of relationship marketing success also confirmed that the presence of sociality was viewed by the respondents as one of the dimensions of relationship marketing designed to ensure social interactions between the bank account officer and the customers. The account officer, he said, is expected to establish a social relationship between customers and the bank, while it is expected that social functions such as birthday, coronation, marriage anniversaries, child dedication, and burial ceremonies are graced by the banks with full commitment. This is done in order for the measures of relationship marketing to be effective and possibly last a life time, leading to loyalty, commitment and quality services that would generate benefits as represented by high customer retention, low costs reduction and higher market share.

In addition, he discovered still that there is a relationship that exists between the operators i.e. the accounts officer (Marketer) and the customer on one hand, the bank and the customer on the other. The study revealed that the strength of this relationship between these players affects business performance. It was discovered that, the relationship between customers and account officers (marketers) is very strong, while that between the bank and the customer though, existing is not as strong as that of customers and the account officers. The study further revealed that the customers believed that the account officer is the bank, so whether it is the account officer or the bank that they deal with, the relationship is not affected.

Based on his findings, Ahiauzu concluded that good inter-personal interaction between an account officer 
and the customer has motives of creating a positive valued system, driven toward long-term relationships, trust and commitment. Corroborating this finding further, Cousins et al (2006, p. 854) submitted that, informal processes create inter-personal linkages that stimulate the formation of trust and respect between individuals within the relationship. Again, Lawson et al (2007, p. 4) state that, "off-site workshops, away days, social events and communication guidelines allow individuals the time and opportunity to strengthen and broaden the relationships at an inter-personal level".

In 2008, Tiffany Derville Gallicano, conducted a research on personal relationship strategies and the outcomes of personal relationships in a Multi-Tiered Membership Organization. He examined ways that an organization's employees cultivate personal relationships using a health advocacy organization (HAO) as a case study. This case study included interviews with 39 staff at national, state, and affiliate levels of the organization; 58 members; and five former members, for a total of 102 participants. The interviews lasted between five minutes and three hours.

A secondary method used by the researcher was participant observation, which consisted of attending and analyzing social activities of a person or group to gather research. 49 hours of participant observation over a four-month period was completed. Gallicano also used content analysis as a supplemental method, using magazines and reports on the organization's history and culture.

This study resulted in the discovery of strategies for cultivating personal relationships, and in identifying outcomes of strong personal relationships in the context of the relationship between the health advocacy organization and its members. It also produced interpersonal influence and management strategies for cultivating personal relationships. Listed below are some of the interpersonal influence strategies as identified by Gallicano

Cheng-Ter and Chang (2011) carried out a study on the Antecedents of Relationship Quality and Loyalty of Urban Business Club: Landmark Club. A total of 127 members of Landmark Club were surveyed by convenience sampling. The results revealed that customer-employee interaction results in customer overall satisfaction, thereby improving the relationship quality. He therefore concluded that the better the relationship quality is, the better would be the customer loyalty and recommended that the club needs to get in touch with their members frequently, providing immediate messages to attract their interests repeatedly and update their information.

This study by Cheng-Ter, et al recognize interpersonal communication (customer-employee interaction), which is an independent variable in the current study, as playing a central role in organization public relationship success. The result of this study will either corroborate or challenge the findings.

In 2011 also, Chantal Rootman conducted a study among bank managers and bank clients to determine the influence of relationship marketing on customer retention. The study samples consisted of banking clients and bank managers in South Africa, Canada and the United Kingdom. The empirical investigation he conducted among banking clients revealed that significant positive relations exist between six of the seven identified variables, namely communication, personalization, empowerment, ethics, fees, and technology and banks' relationship marketing. That implied that if each of these variables improves, bank-client relationship would also improve. On the other hand his investigation among bank managers showed that managers only regarded fees and communication as influences of relationship marketing in banks. This result he said clearly indicated a variance in the viewpoints of banking clients and bank managers.

The study thus concluded that relationship marketing positively influences the customer retention of banks. This he says implies that if banks successfully maintain relationships with their clients, the customer retention rates will increase.

Rootman's study is one of the few that were conducted on bank-customer relationships. Even though the investigation is not exactly on the communication component of relationship marketing, his study confirms that communication among six others positively influences relationship marketing and management and that if each of these variables improves, bank-client relationship would also improve. The result of this present study is an attempt to further this research.

Fagbemi and Olowokudejo, (2011) investigated the relationship management strategies of Nigerian banks and insurance companies. The study was aimed at finding out if banks and insurance companies in Nigeria use customer relationship management as a marketing strategy, as well as whether these organizations have employed the same variables to achieve relationship management success It compares the CRM strategies of both institutions, with the aim of finding out if there is any difference or similarity between their strategies. The survey research design was used and the instrument for data collection was the questionnaire, which was administered to 499 respondents of eight selected banks and twelve insurance companies in Lagos, Nigeria. The target population of the study consisted of branch managers, marketing managers, customer care managers, among other employees of these banks and insurance companies. The instrument measured the relationship between their organizations' CRM strategies and organizational performance.

The study found out that both banks and insurance companies in Nigeria use customer relationship management as a marketing strategy, but that it is more obvious in the banks than insurance industry, probably 
because of the peculiar nature of insurance business and other factors in the external business environment of the Nigerian insurance industry. Findings also show that the strategies adopted by these two companies to achieve customer relationship management goals differ, except in the use of customer focused services and friendliness of employees. It was also observed that customers' rating of the implementation of CRM strategies was lower than that of the employees, especially in the insurance companies. The researchers therefore concluded that the existence of customer relationship management in an organization can only be judged by customer perception. It can only be said to truly exist when the customer says so. There therefore recommended that organizations should educate their customers on their marketing plans and strategies through stakeholder forums, where they could discuss issues of common interest. This according to them will afford organizations the opportunity to have inputs from the stakeholders and be able to synchronize all the opinions expressed, so that perceptions of the organizations tally with those of the customers. The researchers therefore concluded that banks and insurance companies have good relationship management strategies in place and that the organizations are performing very well.

This research was both customer and employee focused. The disparity in the employee and customer perceptions of the organizations' relationship management strategies necessitated the recommendation that there be a better enlightenment strategy for customers of the organizations plans and strategies. Again, the study highlighted the relationship between relationship management and organizational performance.

Ogbalu, E. E. and Usman, A. (2012) also investigated the imperatives of customer relationship management in the Nigerian banking industry, motivated by poor handling of customer complaints, lack of courtesy, poor service quality, inadequate information to customers, unprofessional conduct or rudeness by bank staff, nonavailability of staff at service points, and a long line being experienced in the banks, among others. The objective was to examine the contributions of effective customer relationship management to customer loyalty and profitability of banks. The study surveyed four selected banks: FBN Ltd, UBA, and Zenith and Access banks. 600 respondents consisting of customers and staff of these banks were sampled using questionnaires for data collection.. The study found that there is a direct relationship between customer relationship management and bank performance through customer satisfaction. It also emphasized the role of the employee and IT (information technology) in achieving profitable customer relationship management. The study therefore concluded that customer relationship management leads to customer loyalty. The study therefore recommended that bank managements should pursue customer relationship management programmes with vigour in order to achieve the business objectives of the bank. (www.arabianjbmr.com.).

In 2013, Adedeye conducted a study on 'The impact of relationship management on perceived bank performance in Oyo Town, Nigeria. The objectives of the study were to determine the relationship between the variables measuring customer relationship management (bonding, trust, commitment, communication and satisfaction) and bank performance. Survey research was employed, and the measuring instrument was the questionnaire, which was distributed to 113 employees of selected banks in Oyo State. The banks were Stanbic, GTBank, Zenith Bank, Eco Bank, UBA and Skye Bank.

The findings from the study revealed that commitment independently predicted perceived organizational performance. Also there was a significant difference between bonding and perceived organizational performance, just as trust, communication, satisfaction, commitment and bonding jointly and independently predicted perceived organizational performance. This means that these variables were predictors of organizational performance. This study, the researcher said, supported earlier researches on the impact of customer relationship management on perceived organizational performance, and he therefore concluded that successful relationship marketing efforts improve customer loyalty and firm performance through stronger relational bonds.

Adedeye therefore recommended that there is a need for organizations, especially banks, to have good relationships with their customers so as to sustain competitive advantage, and that organizations should take cognizance of their organizational structure to attract and retain qualified employees that can contribute positively to bank performance, and bring about strong and positive relationships.

This study was carried out from the employee perspective only. However, it agrees with earlier studies that relationship management through trust, commitment, bonding and communication among others impacts positively on banks; performance. The study has demonstrated the importance of tacit knowledge in relational sustenance as advocated by Greenberg \& Baron (2000), and Thomson and McHugh (2002). This present research focuses on the contribution of the communication component, specifically, interpersonal communication to the achievement of relationship management goals as well as banks organizational objectives.

Kenneth, C. Adiele and Justin, M. O. Gabriel in 2013, conducted an empirical validation study on customer relationship management (CRM) and bank performance. The study was focused on Nigeria money deposit banks. The objectivist research strategies were adopted, and major decisions based on nomothetic methodology. 10 retail banks were sampled in the south-south zone of Nigeria. 40 copies of questionnaires were distributed to the banks' general managers and other top management staff who have direct contact with customers. The study shows that a significant relationship exists between CRM and business performance. The study also shows that 
among the three dimensions of CRM studied - customer identification, customer attraction, and customer retention, customer identification and retention impact more significantly on business performance of retail banks in south-south zone of Nigeria. The study thus recommended that Nigeria retail banks should generally increase their customer relationship management strategies to enhance the level of their business viability and specifically review their customer attraction and retention policies in order not to lose customers to competitors (www.reseachgate.com).

Nwankwo, S. I., and Ajemunigbohun, S. S. (2013) carried out an empirical assessment of Customer Relationship management and customer retention in the Nigerian insurance industry. The purpose was to examine the inter-relationships among customer relationship management, customer retention and value creation, with a view to finding out if value creation has extended to the insurance populace in Nigeria. The need for the study, according to the researchers, stemmed from the fact that, despite the effect of the forces of globalization, the insurance industry in Nigeria had become very dynamic in the recent past. Therefore the insurance companies found reason to look towards relationship management in order to creat value that would meet up with the vision, mission and integrity of the organization as well as the expectations of their customers. The study carried out a cross-sectional survey of Lagos metropolis, sampling 58 respondents made up of marketing managers and underwriting mangers from 35 insurance companies. The study found that customer relationship management influences customer retention positively in Nigerian insurance companies, and helps create value for the insuring populace in Nigeria. The study thus recommends that insurance companies should embrace customer relationship management in order to achieve customer retention. (www.omiconline.com)

In 2014, Alawiye-Adams Adewale and Babatunde Afolabi investigated the effects of customer relationship management on bank performance in Nigeria. The objectives were to consider the operational challenges that banks encounter in a bid to satisfy their customers, as well as identify key staff issues that may exist with customer relationship management and lasty to consider if customer expectations were met by the banks. Three banks: access, Wema, nad Skye Bank were sampled. The survey sampled 200 customers and staff drawn from these banks. The instrument of data collection was the questionnaire.

The study showed that customer relationship management has a positive impact on banks, and that the concept is in use by banks and other organizations as a business strategy to increase profitability through customer satisfaction. It showed also that customer satisfaction leads to customer retention. For some banks, customer relationship management starts right from the gate of the banks till when the customer's transaction is concluded. The study recommended among others that bank staff should be adequately and continuously trained on practices in customer relationship management. They should also be given frequent seminars to remind them of the importance of CRM to update their knowledge (www.researchgate.com).

The four studies above investigated customer relationship management, which involves the use of technology to capture efficient and effective customer information, so as to be able to respond to negative customer satisfaction indices and changing customer information. Both studies showed that CRM increased customer satisfaction, which in turn improves relationships between the banks and their customers, and this indicates their relevance to this study.

\section{Theoretical Framework}

The Excellence Theory of public relations and the Uncertainty Reduction Theory of interpersonal communication provide theoretical underpinnings to this work.

\section{The Excellence Theory of Public Relations}

The Excellence Theory is a theory of public relations that 'specifies how PR makes organizations more effective, how it is organized and managed in order to contribute most to organizational effectiveness, the conditions in an organization and their environments that make organizations more effective, as well as how the monetary value of PR can be determined'.

The excellence theory is very relevant to this study because it explains that communication can be used to manage relationships between the organization and its publics. Relationship between customers and employees in Nigerian banks often involves interpersonal communication. It also emphasizes a two way symmetrical communication that characterizes interpersonal communication, as well as a symmetrical model of internal communication in an organization. The theory recognizes that employee communication is very important as that determines how the employees will communicate with the customers who interact with them daily in the course of their business. This study investigates, among others, how the quality of interaction among bank employees influences their interaction with the customers, and how this affects the banker/customer relationship. The excellence theory, despite these criticisms, is therefore adopted as the theoretical basis of this work. This is to determine the extent to which the principles proposed in the theory are practicable in service organizations such as banks, in the building and maintenance of relationships. 


\section{Hypotheses}

Three hypotheses associated with interpersonal communication and relationship building and maintenance were tested for this study. They are stated below:

Hypothesis 1:

Achieving sustainable banker/customer relationships will be related to

the employment of appropriate communication strategies by banks.

Null Hypothesis: Achieving sustainable banker/customer relationships will not be related to the employment of appropriate communication strategies banks.

Hypothesis 2:
Language and listening skills are likely to reduce ambiguities in Communication and improve bank-customer relationships.

Null Hypothesis: Language and listening skills are not likely to reduce ambiguities in communication and improve their relationships.

Hypothesis 3: The quality of employee-customer interaction is likely to positively or negatively affect bank-customer relationship.

Null hypothesis: The quality of employee-customer interaction is not likely to positively or negatively affect bank-customer relationship.

\section{RESEARCH METHODOLOGY}

\section{Research Design}

The in-depth interview was used to help bring out hidden meanings from the responses of the respondents which among other things included their perception and understanding of relationship management and whether they see communication as playing an important role in achieving relationship management goals in their banks.

\section{Population/Study Area}

There are two population groups for this study. The first group comprises all the customers that patronize the commercial banks in the South East region, while the second population group consists of the bank employees who interact daily with the customers in the course of the relationship- relationship managers, branch service managers or heads of operation of all the selected bank branches. The physical setting for the study was made up of all the five states of South Eastern Nigeria, where these commercial banks are located, vis-à-vis, Abia, Anambra, Ebonyi, Enugu, and Imo.

\section{Sample Frame}

The sample frame of this study was therefore derived from the twenty-one commercial banks shown the list of current banks in table one.

Table two displays the 15 selected bank branches in South-East, as well as well and their corresponding states and customer population. The customer base of bank branches is not published in the company reports or profiles. These figures were therefore obtained from the field - directly from the banks confidentially. Due to the large number of banks under study, their profiles are not included here, but are attached as appendix IV. 
Table 2:

Sample Frame for study

\begin{tabular}{|l|l|l|l|}
\hline STATE & & BANK & CUSTOMER POPULATION \\
\hline ABIA & 1 & First Bank Nigeria Limited, Aba Main Branch & 15000 \\
\hline & 2 & Zenith Bank, Umuahia Market Branch & 12000 \\
\hline & 3 & $\begin{array}{l}\text { Guarantee Trust Bank, Aba-Owerri Road, Aba } \\
\text { Main Branch }\end{array}$ & 12500 \\
\hline ANAMBRA & 4 & $\begin{array}{l}\text { Union Bank Of Nigeria Onitsha Main Market } \\
\text { Branch }\end{array}$ & 12000 \\
\hline & 5 & $\begin{array}{l}\text { Diamond Bank Enugu/ Onitsha Express Way } \\
\text { Awka }\end{array}$ & 8200 \\
\hline & 6 & First City Monument Bank, Oraifite Rd, Nnewi & 9500 \\
\hline EBONYI & 7 & Uba Abakaliki Branch & 10500 \\
\hline & 8 & Access Bank, Afikpo Branch & 8000 \\
\hline & 9 & Fidelity Bank, Abakaliki Branch & 4000 \\
\hline ENUGU & 10 & Main Street Bank Okpara Avenue Branch & 5000 \\
\hline & 11 & Enterprise Bank Ogui Branch & 2000 \\
\hline & 12 & Unity Bank Ogbette Branch & 3000 \\
\hline IMO & 13 & Key Stone Bank, Owerri Bank Road Branch & 5000 \\
\hline & 14 & EcoBank, Owerri bank Road & 4000 \\
\hline & 15 & Sterling Bank, Owerri Douglas Branch & 3000 \\
\hline & & TOTAL & $\mathbf{1 1 3 , 7 0 0}$ \\
\hline
\end{tabular}

Source - Field Work, 2015

\section{Quantitative Design - Survey}

To generate quantitative data on communication strategies and patterns of interpersonal communication used by banks in the achievement of relationship management goals, the survey research method was employed. The sample for the research design consisted of customers drawn from the branches of the fifteen banks selected out of the twenty one banks in the South Eastern states of the country. Detailed below, are the sample size and sampling selection procedure.

\section{Sample Size}

A sample size of 400 was used for this study. In determining the sample size, selection was based on Taro Yamani's formula for sample size determination.

Using this formula, we have a sample size of 400 for customers as shown below:

$$
\begin{array}{cl}
\mathrm{n}= & \frac{\mathrm{N}}{\left(1+\mathrm{N}(\mathrm{e})^{2}\right)} \\
& \frac{113700}{(1+113700)} \\
& \frac{113700}{1+113700(0.0025)} \\
& 1+(113700 \times 0.0025) \\
& 1+489.25 \\
& =284.25 \\
& \frac{113700}{284.25}=400
\end{array}
$$

Based on this calculation, as well as the suggestion made by Nwuneli (1991) that the bigger the sample the better for statistical inference, a population of 400 was decided upon as described in the sampling procedure.

\section{Sampling Selection Procedure}

This involved a multi- stage sampling technique. For the purpose of this study, a combination of the probability and non-probability (convenience or opportunity) sampling methods was used. This was occasioned by the fact that lists of banking clients are not readily made available to the public because of the confidentiality of information promised by banks to their customers.

The first stage of the selection procedure involved choosing the banks from each of the five South Eastern states to be sampled. Fifteen banks, representing 71 percent of the total number of banks were randomly 
selected from the twenty one commercial banks operating in South Eastern Nigeria; three banks from each of the five states that constituted the region. Next one branch was also randomly selected from each of the 15 selected banks, giving a total of fifteen branches. As was explained earlier, for the purpose of this study and because of the number of banks involved, the banks were divided into two categories: the New and Old Generation banks to allow for a cross tabulation analysis. The random selection resulted in the emergence of eleven new generation banks and four old generation banks. The new generation banks are Access, Diamond, Eco, Guarantee Trust, Sterling, FCMB, Fidelity, Unity, Enterprise, and Key Stone Banks. The old generation banks are First Bank, Union Bank, UBA and Mainstreet Bank.

The second stage involved a determination of the number of bank customers to be sampled from the selected fifteen bank branches. Out of 113700 working customer population (key information provided by the banks), a sample of 400 was chosen using Taro Yamani's formula as shown above. This was distributed proportionally as explained below:

On the average, each branch should have approximately 26 samples but because the customer strengths of all the branches are not equal, a high and low end selection method was used in four proportional distributions in order to make for evenness. In the first distribution, all the banks that had 10,000 customers and above got 30 samples each, and the total number is five. Secondly, five other banks that had between 5000 and 9999 customers got 26 samples each, while four banks that had between 3000 and 4999 customers got 25 samples each. Lastly, the only bank that had below 3000 customers, got 20 samples. This is illustrated thus:

From 10,000 and above customers: 5 x $30=150$

$\begin{array}{ll}5000-9999 \text { customers } & 5 \times 26=130 \\ 3000-4999 \text { customers } & 4 \times 25=100 \\ \text { Below } 3000 & 1 \times 20=20 \\ \text { Total } & 400\end{array}$

Based on the above, therefore, a sample of 400 for this study is considered adequate for a $5 \%$ error tolerance.

\section{Instrument for Data Collection}

A pre-coded 57-item questionnaire (see appendix A) was used for data collection in this study. The questionnaire is for the customers of the banks and the items were designed to address the variables directly related to the research questions and hypothesis developed for this study.

\section{Questionnaire Design}

The questionnaire is made up of six sections with eight pages and 57 items. The first segment contains five questions on the respondents' demographic data. The second contains nine questions on the communication strategies employed by banks in driving the relationship management concept. The third segment contains seven questions which sought to find out the place of interpersonal communication in relationship management, that is whether one on one or face to face interaction is still relevant or not in today's banking relationships and so should be retained or otherwise as a core communication strategy in banks. The fourth is made up of thirteen questions on the different interpersonal communication patterns in use in the banks, the most and the least popularly used by the banks. The fifth section contains fourteen questions on the relationship management strategies employed by banks and their effect on customer relationships. The last is made up of nine questions which focus on how interpersonal communication has affected the banks' relationships with the customers.

\section{Qualitative Design - In-Depth Interview}

An in-depth interview was conducted on the bank employees to compliment the responses received from bank customers about the relationship management concept in banks and how this affects their relationship with the bank.

\section{Selection of Interviewees}

The interviewees consists of relationship managers, head of operations or branch service managers as well as heads of customer service, who interact with customers daily in all the sampled banks. Since bank employees are closer to bank customers, they are most likely in a better position to provide valuable insights on customer relationship management practices. One senior staff; that is a management staff or head of department in the branch was sampled from each of the 15 selected banks. The instrument for data collection in this case is the interview schedule, consisting of a set of open- ended questions which were administered to a managerial or any senior staff in each of the fifteen bank branches sampled. The interview schedule was designed in a way that provides detailed background information about relationship management practice in the banks, with special emphasis on interpersonal communication and its effect on bank customer relationships. 


\section{In-depth Interview Questions (Interview Schedule)}

Questions for the in-depth interview used to elicit qualitative data for the study included:

- Bank employees' perception of relationship management, and strategies employed by banks in maintaining relationships.

- Communication strategies put in place by banks in order to achieve relationship management goals, as well as the communication patterns in these banks.

- The relevance of interpersonal communication in banks' business relationships as well as the interpersonal communication patterns in use by banks in relationship management.

- The role of relationship management in the achievement of banks' organizational objectives.

- The quality of interaction among the employees was assessed in order to determine whether healthy communication among the employees positively affected their interaction with customers in relationship building and maintenance.

- The impact of interpersonal communication, both verbal and nonverbal on the achievement of relationship management goals.

\section{Data Collection}

Data collection was conducted in two phases. The first phase took place in the months of January and February, 2015 and covered an eight week period. The data were collected by administering the questionnaire containing a total of 57 items to bank customers of the selected bank branches spread across the five south eastern states of Nigeria. Four trained research assistants were engaged for this exercise to assist the researcher in covering all the five states. They distributed and collected copies of the questionnaire from the customers of the various bank branches in the states assigned to them and who were present at the banking hall at the time of their visit within the space of seven days. Some of the customers also provided referrals to the assistants to ensure adequate sample representation. Each of these assistants plus the researcher administered between 20 and 30 questionnaires to respondents in each of the three selected bank branches in their state of coverage. Each had a $100 \%$ return rate, although about four questions in four of the questionnaires were not responded to. This accounted for one unanswered question out of 57 per questionnaire. This was considered negligible to negatively affect the results of the analyses. However the missing data accounted for the variations in the frequencies during the analyses. The second stage required the research assistants to visit the branches again and conduct interviews with some of the bank employees selected, and who were willing to participate in the survey. This stage of the research took place in March, 2015. The research assistants succeeded in interviewing all the categories of bank employees.

\section{Method of Analyses}

The quantitative data analyses were done with the aid of the Statistical Package for Social Sciences (SPSS), version 16. Chi-Square, as well as simple tables and percentages were used to analyze and compare the data collected with the theories used for the study. Written case analyses were also used to find out similarities and differences between the findings from the questionnaires and the in-depth interview analysis as well as the theoretical background described in the literature review of this work. Pierson's product moment correlation statistics was used to establish probable relationships between the dependent and independent variables in order to enable us test our hypotheses. The descriptive thematic method was applied for the qualitative data. This involved transcription of interviews, and thematic analysis of categories to extract meanings.

\section{DATA PRESENTATION, ANALYSIS AND INTERPRETATION}

The first section of this chapter deals with the analysis of the survey instruments and is presented as follows:

\section{Response Rate}

A total of 400 copies of the questionnaire were distributed to the selected banks studied in the South-Eastern Nigeria. The total number of questionnaires returned was 400 , representing $100 \%$ return rate. This is because the research assistants met the customers right at the banking halls, administered the questionnaires and waited and collected them immediately. Against the backdrop of Myer's sample of 384, and the calculated sample of 400, using Taro Yamani's formula, as well as the suggestions of Stack \& Hockings (1999 and Nwuneli (1991), this response rate was considered appreciable enough to provide the necessary data for this study. However, among the returned copies of the questionnaire, about four questions in four different questionnaires were discovered not to have been answered by the respondents. This represented one question out of 57 per questionnaire. This was considered, as was stated earlier, not significant enough to adversely affect the result of the analysis, since it did not constitute up to one percent of the questions, but was nevertheless represented by slight variations in the frequencies. 


\section{Demographic Variables}

The demographic variables of the respondents were measured using questions 1-3 in the questionnaire (see Appendix 1). Data generated from their responses were presented in the following pie charts.

\section{Figure One:}

Age Distribution of Respondents

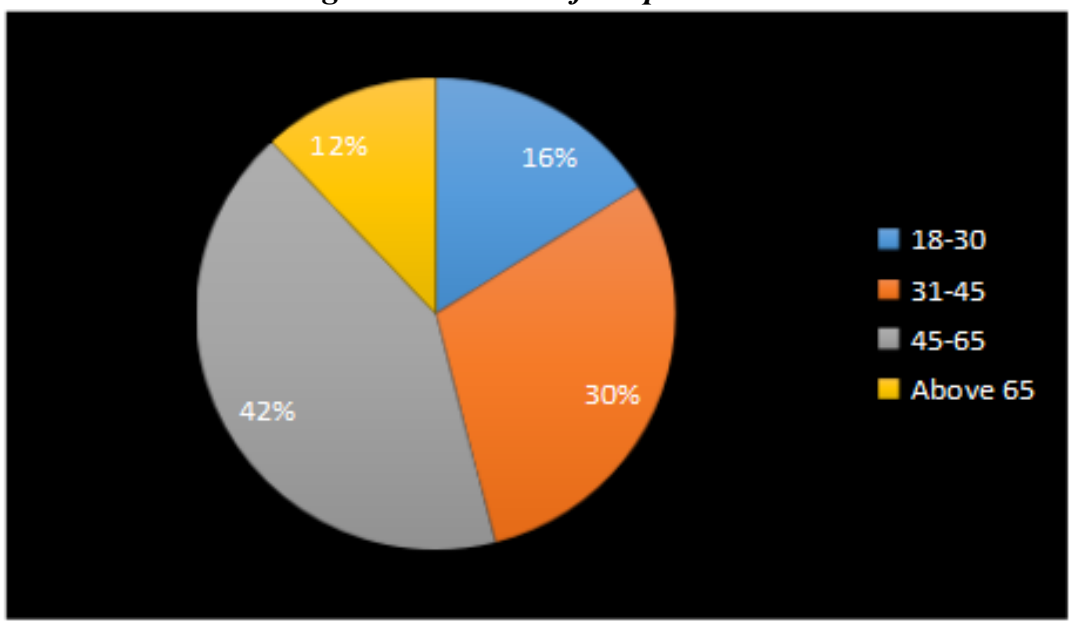

Figure one above shows that more than one third of the respondents that is 42 percent were between the ages of 46 and 65, while about one-third, that is 30 percent were made up of those in the age bracket of 31 to 45 . Whereas about one-quarter, that is 16 percent were between the ages of 18 and 30,12 percent were above the age of 65 . The data suggests that the customers in the age brackets of 31 and 65 constitute the highest population sampled. This represents the age bracket of active customers who do business with the banks.

Figure Two:

Sex Distribution of Respondents

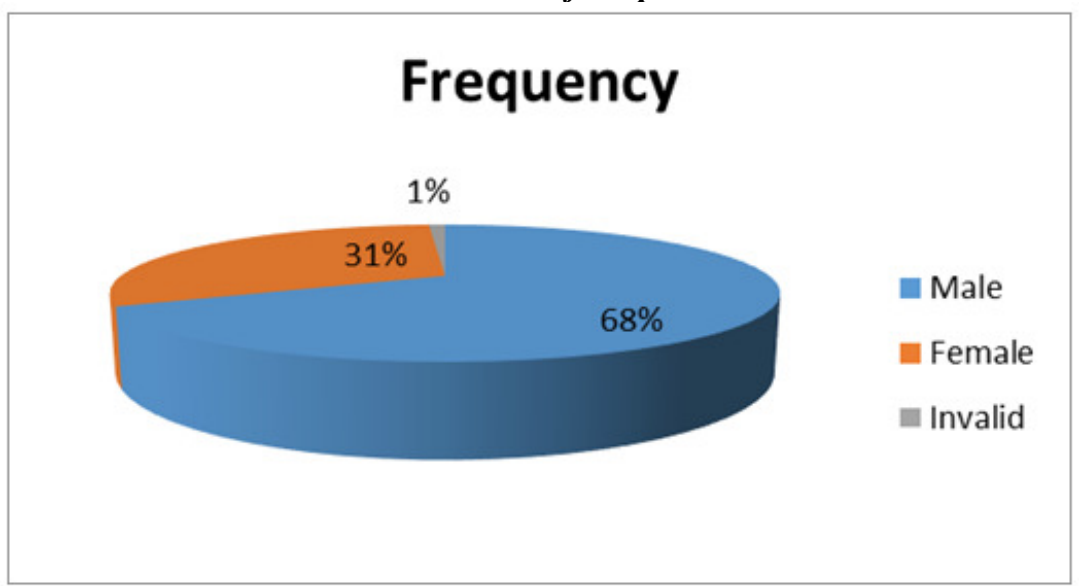

Figure two above shows the gender distribution of the respondents from the various sampled banks. More than half of the 400 respondents, that is 272 or 68 percent were males, while about one-third, that is 124 or 31 percent were females. This demonstrates that more males than females engage in banking activities. The remaining four, that is one percent accounted for those who did not answer this particular question.

A cross tabulation analysis was then carried out to determine if there was any relationship between the respondents' gender and age. The result of this analysis is presented in the table and chart below.

Table 3

Relationship between Respondents' Age and Sex

\begin{tabular}{|l|c|c|}
\hline \multirow{2}{*}{ AGE OF RESPONDENTS } & \multicolumn{2}{|c|}{ SEX } \\
\cline { 2 - 3 } & MALE & FEMALE \\
\hline $18-30$ & $20 \%$ & $20 \%$ \\
\hline $31-45$ & $50 \%$ & $70 \%$ \\
\hline $46-65$ & $20 \%$ & $7 \%$ \\
\hline Above 65 & $10 \%$ & $3 \%$ \\
\hline Total & $100 \%$ & $100 \%$ \\
\hline & $\mathrm{n}=271$ & $\mathrm{n}=125$ \\
\hline
\end{tabular}


Figure Three:

Relationship between Respondents' Age and Sex

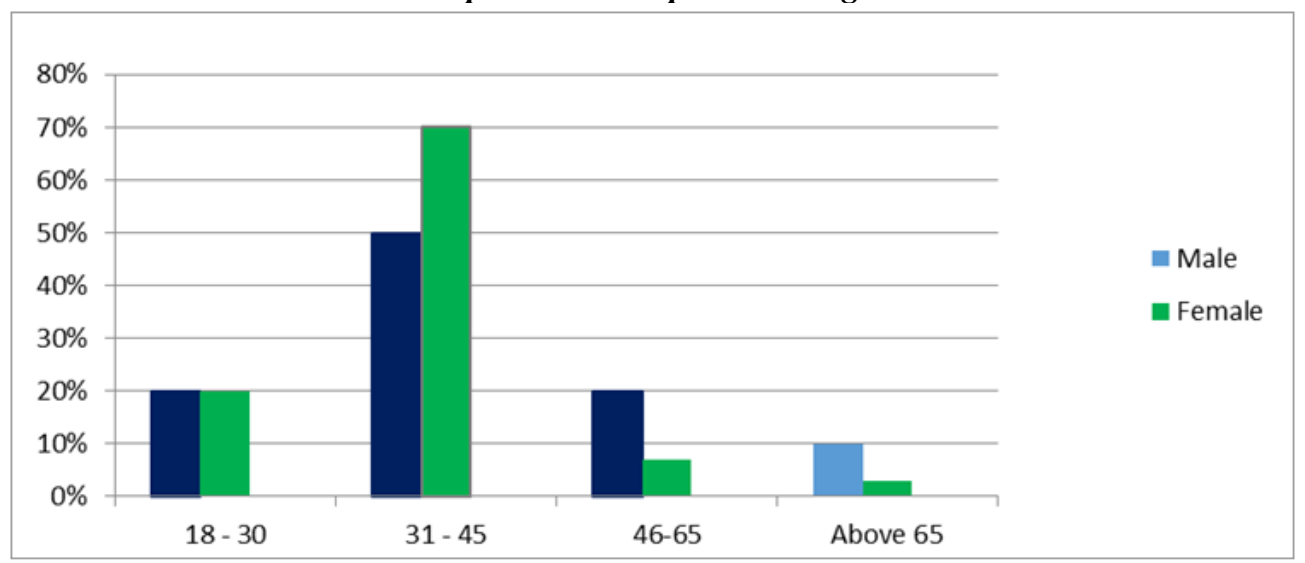

The relationship between the respondents' age and sex was intended to show the age distribution of the respondents in each gender, in order to determine which gender had the oldest and the youngest respondents. The analyses in table four as well as figure three show that while more than two-thirds, that is, 70 percent of the female respondents were within the age bracket of 31 and 45; only half, which is 50 percent of the males, fell within this age bracket. Again less than one third, that is 20 percent of both sexes fell between 18 and 30 years, whereas, the males topped the chart in the ages between 46 and 65 as well as above the 65 age bracket. This represents 20 percent against seven percent and 10 percent against three percent for male and female respectively in the two age brackets. The result of this analysis demonstrates that the females bank clients sampled were generally younger than their male counterparts, as the males outnumbered them in the middle age and the elderly age brackets. This agrees with the previous data that showed that the male respondents appeared to have longer banking experiences than the females.

Next, a distribution of the respondents of the old and new generation banks was presented in table four below. As explained in chapter three, Nigerian banks are popularly identified by old and new generation categories. 'Old and new generation' are terms commonly used to distinguish between the premier banks who operated in the county long before the advent of the newer banks who introduced competition in the banking industry with new wave banking technology and practices. Therefore, because of the large sample population, the banks are also grouped into these two categories to allow for a cross tabulation analysis.

Figure Four:

Distribution of Respondents b/w Old and New Generation Banks

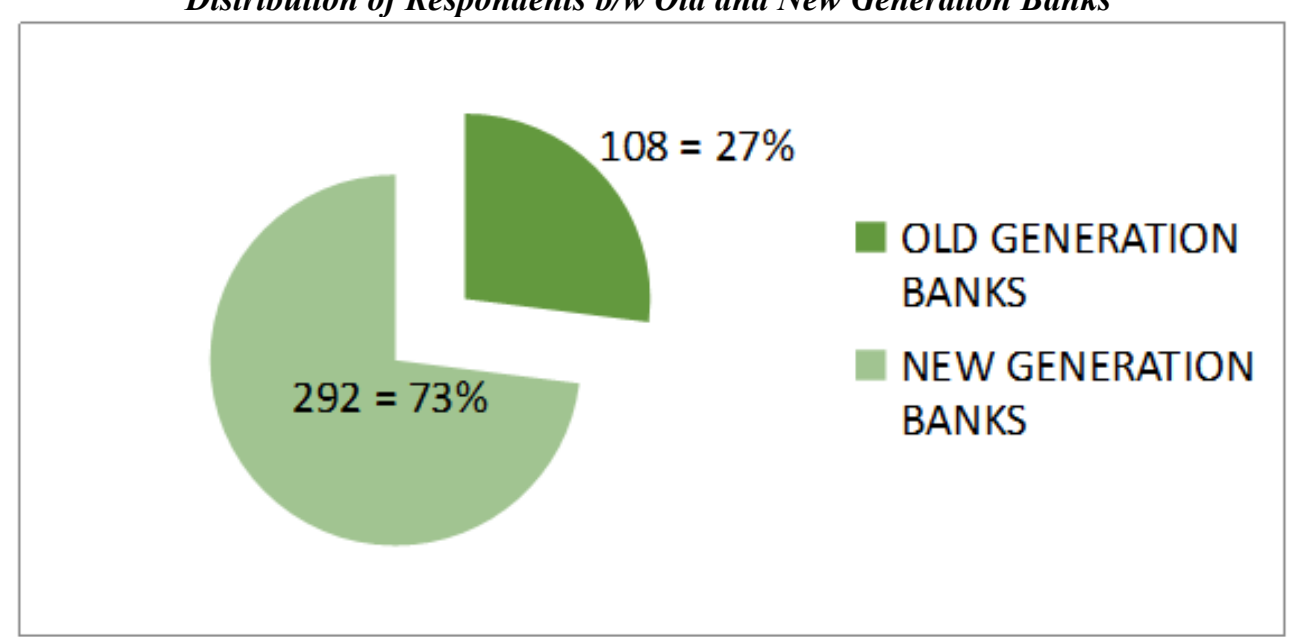

The analysis in figure four shows that the respondents consisted of 108 customers of the old generation banks and 292 of the new generation banks. This represents 27 percent and 73 percent respectively. The new generation banks are of course more in number than the old generation banks and so the number of their customers as well is expected to be greater. Of the total of 15 banks randomly sampled, we had 11 new generation and four old generation banks. Since each bank branch got an equal number of samples, i.e., 27, the population sample of 400 consisted of 108 respondents (customers) of the old generation banks and 292 of the new generation banks. 
Table Four:

Age Distribution b/w Old and New Generation Banks

\begin{tabular}{|l|c|c|}
\hline AGE OF RESPONDENTS & $\begin{array}{l}\text { NEW GENERATION } \\
\text { BANKS }\end{array}$ & OLD GENERATION BANKS \\
\hline $18-30$ & $44 \%$ & $20 \%$ \\
\hline $31-45$ & $38 \%$ & $28 \%$ \\
\hline $46-65$ & $15 \%$ & $29 \%$ \\
\hline Above 65 & $3 \%$ & \\
\hline & & $100 \%$ \\
\hline Total & $100 \%$ & $\mathrm{n}=104$ \\
\hline
\end{tabular}

A cross tabulation analysis by age was then carried out to determine the category of banks which had the greater number of youths, the middle aged and the elderly. The analysis presented in table five above shows that the respondents of the new generation banks who were between the ages of 18 and 30 accounted for 44 percent, that is above one-third, while those of the old generation banks accounted for less than one-third, that is 20 percent. For age brackets 31 and 45, the new generation banks again had a little above one-third, that is 38 percent, while the old generation banks recorded only 23 percent. On another note, the respondents of the new generation banks who fell between the ages of 46 and 65 accounted for 15 percent, less than one-fifths of the population, while for the old generation banks, 28 percent of the respondents, almost one third, were in this age bracket. Finally, only two percent of the interviewees who maintained accounts with the new generation banks were above 65 , while close to one-third, that is 29 percent of the respondent who were customers of the old generation banks fell in the above 65 years age category.

This analysis reveals that in the new generation banks, what seems tenable points to a preponderance of young people, while in the old generation banks the more of the elderly in the society appear to form the majority of their customers. The implication of this is that the old generation banks may face continuity issues as they may not have future customers in the coming generation. There is therefore the need for them to tailor their banking policies and relationship strategies towards attracting the younger customers.

\section{Figure Five:}

\section{Occupational Distribution of Respondents}

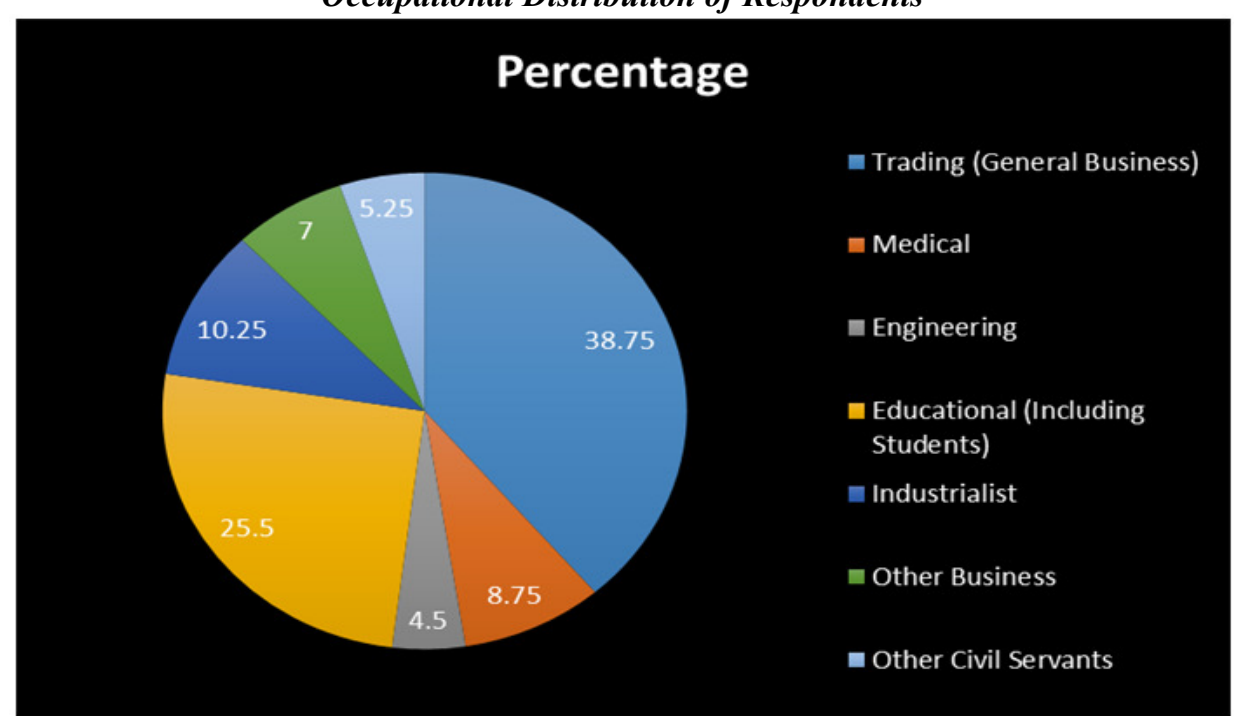

Figure five above displays the distribution of the respondents by occupation. From the analysis, more than one-third $(38.75 \%)$ of the sampled population are engaged in all kinds of trading or general merchandise. This was followed by those in the education sector, who accounted for 25.5 percent, students inclusive. Whereas industrialists accounted for 10.25 percent of the respondents, those in the medical profession accounted for 8.75 percent. Seven percent of the respondents consisted of people engaged in other businesses not specified in the option like artisans and transporters, while other civil servants such as local government workers, police, 
customs and immigration staff made up 5.25 percent. The last slot of 4.45 percent was taken by the engineering profession. This seems to suggest that the respondents consist more of general traders and students than professionals. This corroborates with the nature of the research area. South Eastern Nigeria is known to be an area made up of elites and civil servants, but majority of the males are known to be business inclined. Therefore, this data represents the business oriented nature of the region.

\section{Length of Respondents' Banking Relationship}

The purpose of this section is to determine for how long the respondents have had banking relationship with the bank. This was measured by item four in the questionnaire.

Figure Six:

Length of Respondents' Banking Relationship

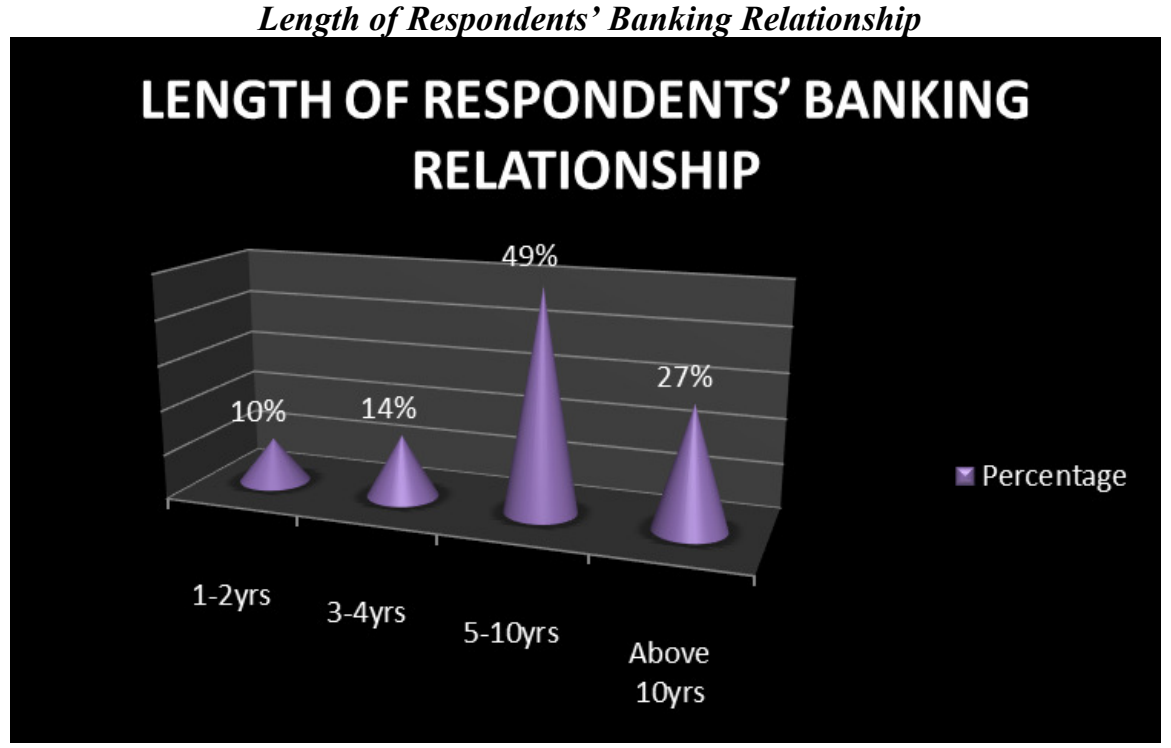

Figure six above shows that 49 percent, that is almost half of the respondents have had banking relationships for between five and 10 years, 27 percent, that is a little above one-quarter had banked for over 10years, while 14 percent have had banking experience for between three and four years. 10 percent consisted of those that had been in banking relationships for only one to two years. The implication of this data is that majority of the respondents (76\%) had been in banking relationships for five years and above, while less than a quarter appears to be new entrants in banking business.

Next, the length of the respondents' banking relationships was analyzed by age, to ascertain if any relationship exists between age and how long customers maintain their accounts with banks. The analysis is presented below.

Table 5

\begin{tabular}{|l|c|c|c|}
\hline How long & Old Generation Banks & New generation Banks & Total \\
\hline $1-2 \mathrm{yrs}$ & $6 \%$ & $4 \%$ & $10 \%$ \\
\hline 3-4yrs & $6 \%$ & $8 \%$ & $14 \%$ \\
\hline $5-10 \mathrm{yrs}$ & $22 \%$ & $27 \%$ & $49 \%$ \\
\hline Above $10 \mathrm{yrs}$ & $15 \%$ & $12 \%$ & $27 \%$ \\
\hline Total & $49 \%$ & $51 \%$ & $100 \%$ \\
\hline & $\mathrm{n}=108$ & $\mathrm{n}=292$ & $\mathrm{n}=400$ \\
\hline
\end{tabular}

Table five above presents a cross-tabulation analysis conducted among the banks to determine if there is any significant difference in the length of customers' banking relationships between the old and new generation banks. The analysis shows an almost even distribution in the number of years the respondents in the two categories of banks had been in relationships with their banks. Six percent of the old generation banks customers as against four of the new had been in banking relationships for between one and two years. Similarly, six percent of the old generation banks customers sampled had between three and four years banking experience, as against eight percent of the new generation banks customers. Whereas 22 percent of the respondents of the old generation banks had between five and ten years banking experience, 27 percent of the new generation banks respondents had maintained bank accounts for the same number of years. Lastly, 15 percent of the old generation banks customers had been in banking relationships for over ten years, while 12 percent of the new generation bank respondents had this length of banking experience. In summary, 39 percent of the new generation banks respondents had been in banking relationships for 10 years and below, while 34 percent of the old generation banks respondents had banked for this long. On the contrary, while 15 percent of the old generation bank 
correspondents have had banking experience for over ten years, only twelve percent of the new generation banks correspondents did. It would have been expected that the old generation banks having operated for much longer periods than the new generation banks would record more customers who had been long in banking business, but that appeared not to be the case. This would seem to suggest that the new generation banks might have taken up a very strong competitive position in winning customers, both old and new.

\section{Communication Strategies in Banks}

This section sought to determine the various communication strategies put in place by banks for the practice of relationship management. This was measured using items six to 14 in the questionnaire. Customers were required to indicate the communication channels that banks use in relating with them and their preference for each. The analysis is presented in the figure below.

\section{Figure seven:}

\section{Communication Strategies in Use by Banks}

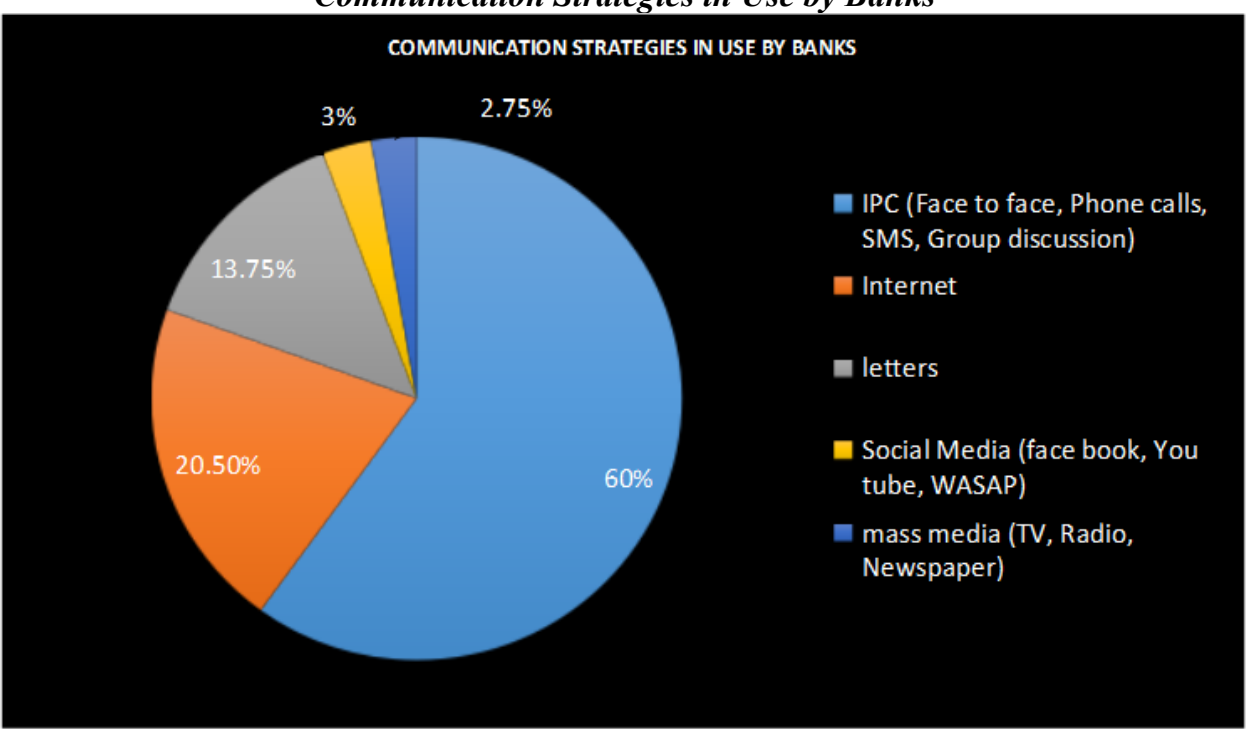

Figure seven above reveals that more than half, that is 60 percent of the respondents affirmed that interpersonal communication or one-on-one interaction is one of the ways that banks communicate with them. While about one-fifth $(20.75 \%)$ of them confirmed that banks do communicate with them through the Internet, 13.75 percent agreed that letter writing is used as a communication strategy by banks. Similarly, three percent and 2.5 percent respectively acknowledged the social and mass media as strategies used by banks to communicate with customers. From the data, it appears that in sampled banks, interpersonal communication, the internet and letters are the most popularly used communication strategies in that order, while the mass media and the social media rank as the least popularly used.

Table Six

Distribution of the Most Frequently and Most Popularly Used Communication Strategies by Banks

\begin{tabular}{|l|c|c|c|c|c|}
\hline Frequency & one-on-one & Internet & Letter & Mass media & Social media \\
\hline Often & $88 \%$ & $15.75 \%$ & $43 \%$ & $1 \%$ & $5 \%$ \\
\hline Sometimes & $12 \%$ & $25 \%$ & $20.75 \%$ & $2.50 \%$ & $8 \%$ \\
\hline Not at all & $0 \%$ & 59.25 & $36.25 \%$ & $96.50 \%$ & $87 \%$ \\
\hline Total & $100 \%$ & $100 \%$ & $100 \%$ & $100 \%$ & $100 \%$ \\
\hline & $\mathrm{n}=400$ & $\mathrm{n}=400$ & $\mathrm{n}=400$ & $\mathrm{n}=400$ & $\mathrm{n}=400$ \\
\hline
\end{tabular}

Although the previous data showed the most commonly used communication strategy in the banks, data in the above table reveals frequency of use of the communication strategies. This is to corroborate the previous data and also determine whether the most popular are also the most frequently used. Table six shows that 88 percent of the correspondents rated interpersonal communication as the most frequently used communication strategy by banks, 12 percent indicated that it is sometimes used, while no respondent recorded that it is not in use at all. Similarly, 15.75 percent of the respondents affirmed that the internet is regularly used to communicate with them, 25 percent said it is sometimes used, while 59.25 percent did not accept that banks do communicate at all with them through the internet. This is followed by letter writing and the social media, in which the respondents rated the frequency of their use as 43 and five percent respectively. While 20.75 and eight percent respectively affirm that they are sometimes used to relate with them, 36.25 percent and 87 percent affirmed that these communication strategies are never used in relating with them. However, 96.5 percent of the respondents 
affirmed that banks do not use the mass media at all in communicating with them. One percent acknowledged its frequent use while 2.5 percent acknowledged that it is occasionally used.

The data indicates that interpersonal communication is the most frequently used channel of communication, while the mass media appear to be the least frequently used means of communication between banks and their customers. Data from this table further corroborates previous findings from table seven. This demonstrates the dominance of interpersonal communication in the communication pattern of banks.

\section{The Place of Interpersonal Communication in Relationship Management}

Even though interpersonal communication has been identified as the most frequently used communication strategy by banks in relating with their customers, this section presents data relative to ascertaining customers' opinion of the use of interpersonal communication in business relationships by banks. The intention is to establish the acceptance of and preference for its use and how relevant the customers themselves think that interpersonal communication still remains in today's business relationships, as well as whether it enhances relationships more than other communication strategies. Respondents' opinions were sought as to whether interpersonal communication should be retained as a core communication strategy or whether it has been rendered dormant by the social media. Items 15 to 21 in the questionnaire were used to discuss this and the analyses are presented below:

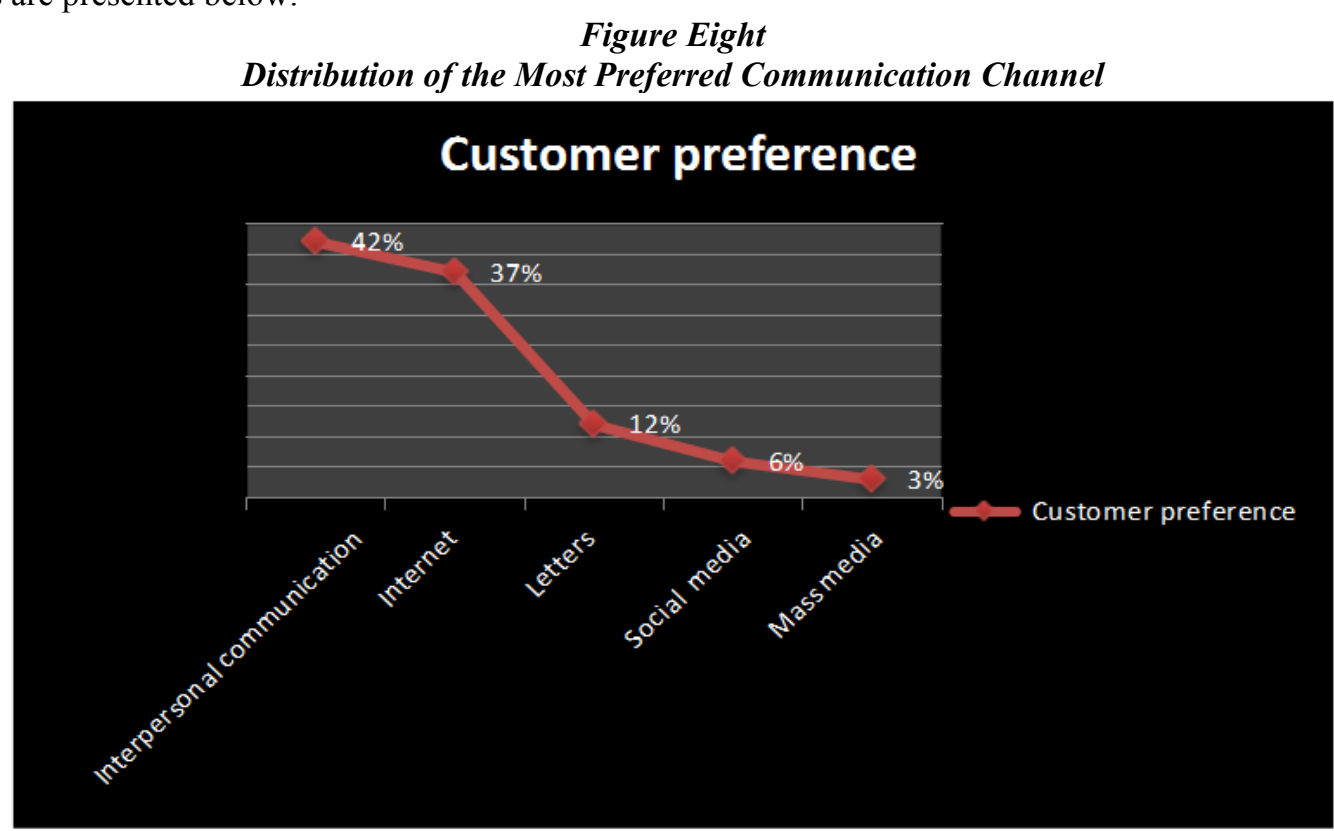

The analysis in figure eight above shows customers' scale of preference as it relates to communication channels. 42 percent, representing three-fifths of the respondent's population indicated communication through the interpersonal channel or one-on-one interaction as the most preferred, whereas about two-thirds, that is, 37 percent opted for the internet. 12 percent of the respondents seem to prefer letter writing as a communication channel, six percent said they prefer the use of social media, while the last three percent went for the mass media. The result of this analysis seems to suggest that most of the customers would prefer communicating with the bank one-on-one, although the margin between the preference for the internet and interpersonal communication appears to be thin.

Customers' Perception and Assessment of the Relevance of IPC

This section of the analysis sought to establish the customers' view and evaluation of the relevance of the use of interpersonal communication by banks in their day to day business activities with their customers. The analyses are presented in figure nine and table eleven below.

Table 7

Customers' Assessment of the Relevance of Interpersonal Communication

\begin{tabular}{|l|c|c|}
\hline & $\begin{array}{l}\text { In your opinion, does IPC enhance } \\
\text { customer relationships more than other } \\
\text { communication strategies? }\end{array}$ & $\begin{array}{l}\text { Do you think it should be retained as a } \\
\text { core communication strategy in banks? }\end{array}$ \\
\hline Yes & $96 \%$ & $98 \%$ \\
\hline No & $4 \%$ & $2 \%$ \\
\hline Total & $100 \%$ & $100 \%$ \\
\hline & $\mathrm{n}=400$ & $\mathrm{n}=400$ \\
\hline
\end{tabular}


The study then sought to establish the opinions of customers about the role of interpersonal communication in relationship maintenance; whether it enhances relationships as well as whether it should be retained as a core communication strategy. Table seven displays the summary of customers' evaluation of interpersonal communication. Majority, which is 96 percent of the respondents, believe that it enhances customer-banker relationships, while four percent have a contrary opinion. Similarly, 98 percent of the respondents are in support that interpersonal communication be retained as a core communication strategy in banks' relationship with their customers, while only two percent are against that. The reason could be that in Nigeria; most of the banking transactions require the presence of customers presently, as only few people are yet exposed to online transactions.

\section{IPC Patterns Used by Banks to Relate with Customers}

This section examined the patterns of interpersonal communication employed by banks to interact and relate with their customers. It also evaluated which among the patterns is the most popularly used, the least popularly used, and the most preferred by customers. The section also sought to ascertain whether the bank employees displayed adequate interpersonal skills and appropriate interactive attitude that would enhance sharing of meanings and interpersonal relationships, such as good listening skills, question asking skills, conflict resolution, simplicity and familiarity of language used, as well as using the right choice of words during interaction.

Table 8

Distribution of Interpersonal Communication Patterns

\begin{tabular}{|l|c|c|}
\hline & $\begin{array}{c}\text { IPC Patterns in Use } \\
\text { by Banks }\end{array}$ & $\begin{array}{c}\text { Preferred IPC Patterns by } \\
\text { Customers }\end{array}$ \\
\hline $\begin{array}{l}\text { One-on-One/face to face } \\
\text { Interaction }\end{array}$ & $53 \%$ & $76 \%$ \\
\hline Phone calls & $5 \%$ & $5 \%$ \\
\hline SMS & $4 \%$ & $10 \%$ \\
\hline Group discussions & $2 \%$ & $7 \%$ \\
\hline All of the Above & $36 \%$ & $2 \%$ \\
\hline & $100 \%$ & $100 \%$ \\
\hline & $\mathrm{n}=400$ & $\mathrm{n}=400$ \\
\hline
\end{tabular}

Table 8 displays data showing the distribution of responses on interpersonal communication patterns in use by banks and the respondents' preference for each. As can be deducted from the table, slightly above half of the respondents, i.e. 36 percent indicate that all the IPC patterns mentioned are in use in the banks. A breakdown of the use of the individual patterns shows that 53 percent of the respondents consider one-on-one interaction as the most popularly used pattern, followed by phone calls, which five percent of the respondents affirm its popularity in usage, whereas four percent of the respondents rated SMS as the third popularly used. From the analysis, group discussion is the least used, with only two percent of the respondents attesting to its use. For the most preferred pattern, more than two-thirds of the respondents, that is, 76 percent preferred to use one-on-one interaction, while 10 percent went for phone calls. Seven percent of the respondents preferred to use SMS, while five percent preferred group discussions. Lastly, two percent preferred all the listed patterns of interpersonal communication. These points to the fact that although banks use different patterns of interpersonal communication in relating with their customers, the customers have greater preference for one on one interaction.

\section{Bank Customers' Perception and Assessment of Relationship Management}

This section looks at the available relationship management techniques employed by banks, with a view to ascertaining the degree to which each of them influences customers' relationship with the banks. Such techniques include communication, employee attitude to customers, service quality, product quality, bonding and socialization, as well as trust. Item numbers 36 to 49 in the questionnaire take care of this, and the analyses are presented in the tables that follow.

\section{Table 9}

\section{Distribution of Relationship Management Techniques by Banks}

Which among the relationship management factors below positively influences your relationship with the bank?

\begin{tabular}{|c|c|c|c|c|c|c|l|}
\hline $\begin{array}{l}\text { Service } \\
\text { quality }\end{array}$ & $\begin{array}{c}\text { Employee } \\
\text { commitment } \\
\text { and attitude }\end{array}$ & Communication & $\begin{array}{c}\text { Bonding/ } \\
\text { Socialization }\end{array}$ & $\begin{array}{c}\text { Product } \\
\text { quality }\end{array}$ & Trust & $\begin{array}{c}\text { All of the } \\
\text { above }\end{array}$ & Total \\
\hline $18 \%$ & $17 \%$ & $17 \%$ & $15 \%$ & $14 \%$ & $11 \%$ & $8 \%$ & $100 \%$ \\
\hline $\mathrm{n}=80$ & $\mathrm{n}=72$ & $\mathrm{n}=60$ & $\mathrm{n}=60$ & $\mathrm{n}=60$ & $\mathrm{n}=40$ & $\mathrm{n}=32$ & $\mathrm{n}=400$ \\
\hline
\end{tabular}

From table 9 above it is observed that about one-sixth (18\%) of the respondents chose service quality as 
their greatest relationship trigger. Employee commitment/attitude to customers and communication came next with 17 percent score each. This was followed by bonding/socialization which 15 percent of the customers opted for. Also, 14 percent and 11 percent of the customers went for product quality and trust respectively, while eight percent of the respondents affirmed that all the factors are necessary for their relationship with the banks to be cordial. The result of this analysis has corroborated previous literature which identified communication as an important component of relationship management. In the respondents' rating communication tied with staff attitude to take the second position in their list of preferences, after service quality. Bonding and socialization also appear to have a great influence on the bank-customer relationship.

Next, the study looks at the merits of the individual relationship management factors and how they affect customers' relationships with the banks. The analyses are presented in the following tables

Figure 11:

Customers' Rating of their Relationships with the Banks

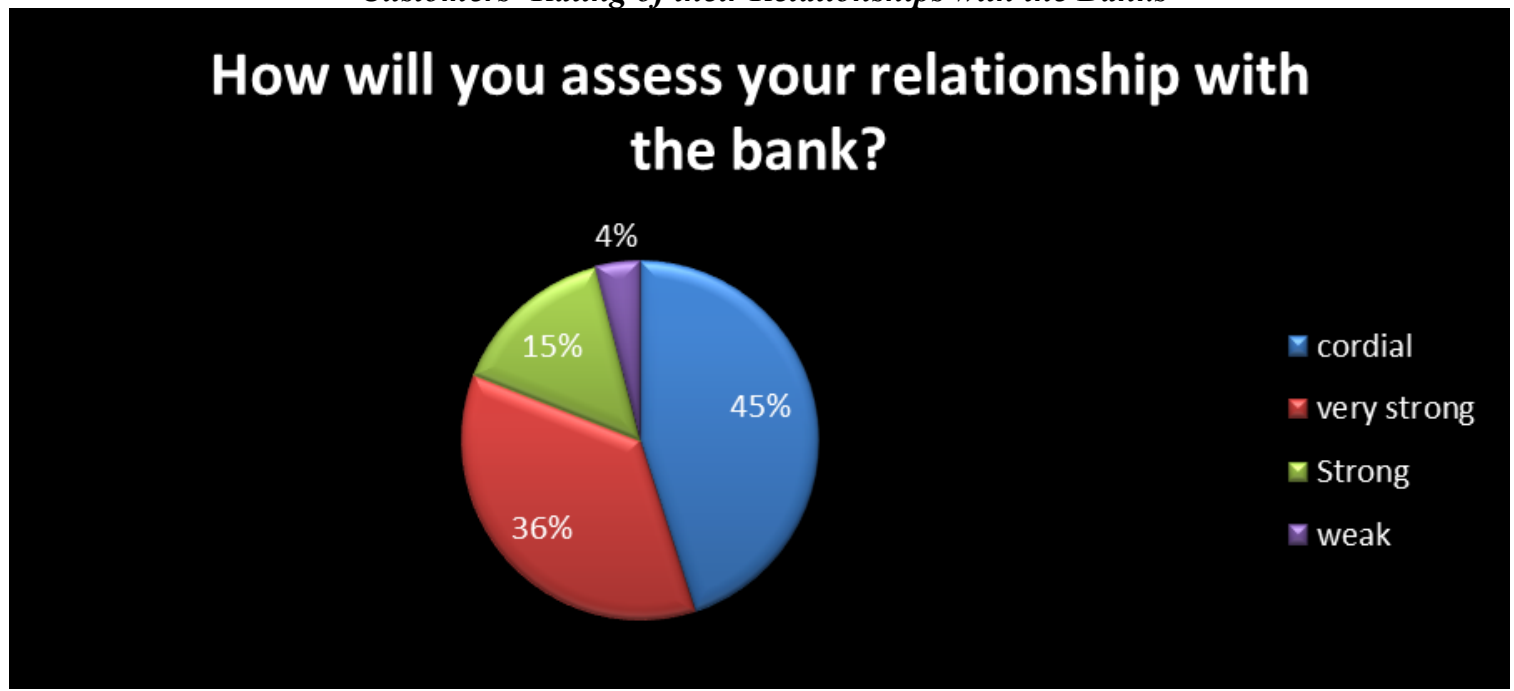

Having demonstrated in the previous data that there is an improved bank-customer relationship arising from the introduction of various relationship management strategies, figure 11 above illustrates customers' assessment of the extent or degree to which these relationship management factors influenced their relationships with the banks. The analysis demonstrates that slightly below half $(45 \%)$ of the correspondents rated their relationship with the banks as cordial. 36 percent felt that their relationship with the banks is very strong, while 15 percent believe that the relationship is just strong. However, four percent of them are still of the opinion that their relationships with their bank is weak. When put together, we find out that the overall assessment of customers is that their relationship with the banks is very good. This probably could be related to the relationship management techniques employed by banks to enhance bank-customer relationship. The analyses therefore corroborates Stanford and Canary (1991) who found that the basic concerns of relational maintenance are to identify healthy and constructive patterns of interpersonal growth and to avert problems in a relationship; warning that when one or more relational maintenance strategies are missing in a substantial and consistent manner from a relationship especially organization-public relationships, it will likely show real signs of distress.

The Influence of Interpersonal Communication on Relationship Management Success in Banks.

Having identified communication as one of the relationship management techniques employed by banks, this section now focusses on ascertaining the extent to which interpersonal communication contributes to the achievement of relationship management goals in banks, and by extension their organizational objectives. To do this, the interpersonal communication strategy was analyzed; using both the verbal and nonverbal cues, and was measured using item numbers 50 to 55 in the questionnaire. Items analyzed include the quality of interaction between bank employees and customers and its effect on the relationship, as well as customers' perception of nonverbal communication cues deliberately or otherwise exhibited by the employees while relating or interacting with them. This is to ensure that appropriate responses are elicited from the respondents to deal with the issue under discourse.

\section{Quality of Employee-Customer Interaction}

The purpose of this section is to find out customers' assessment of bank employees interaction attitude. Item number 52 in the questionnaire was used to address this and the result presented in the figure below. 
Figure 12:

Customers' Opinion of Quality of IPC in Banks

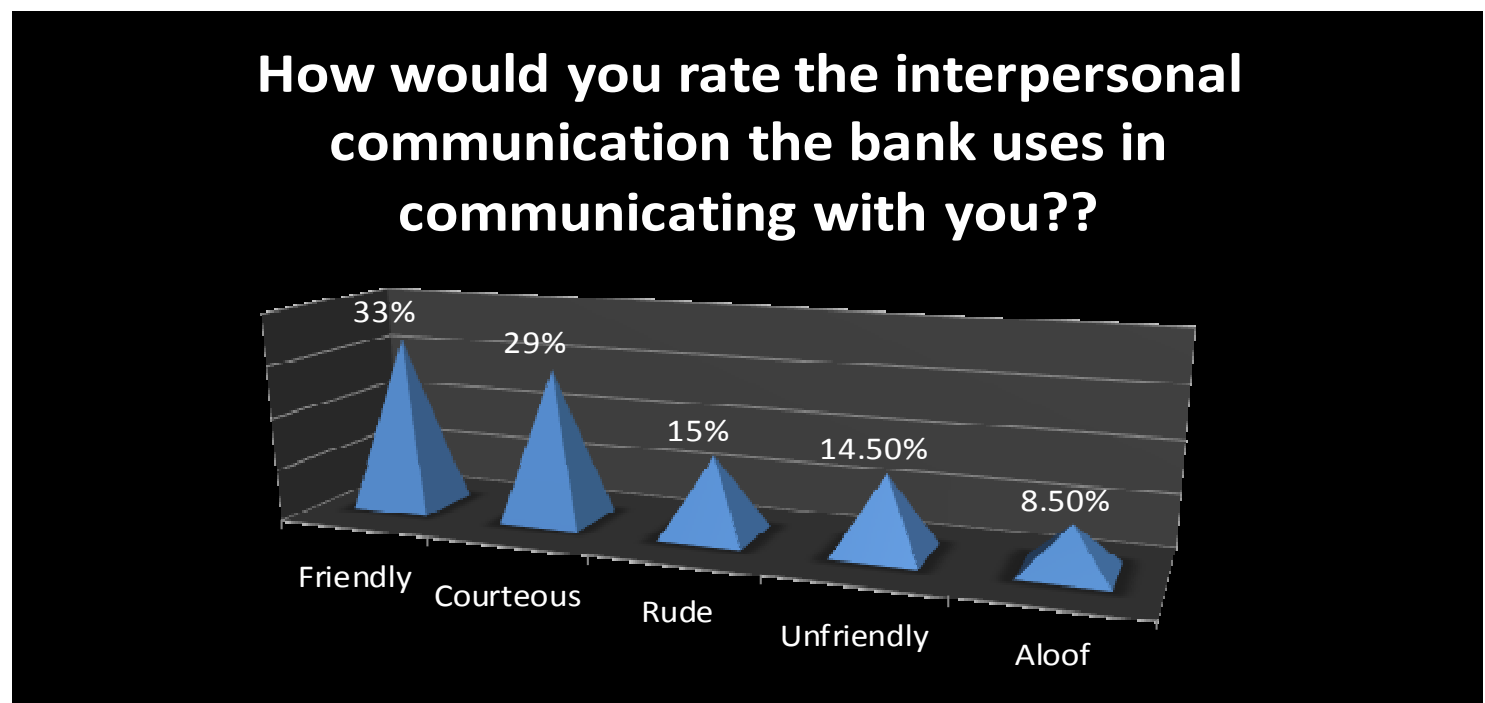

Figure 12 above displays the various opinions of customers on the quality of interaction in the banks. The analysis shows that about one-third (33\%) of the respondents assessed the employee-customer interaction as being courteous, while more than one-fifth (29\%), were of the opinion that it is friendly. Whereas 15 percent affirmed that bank employees are rude in their interactions, 14.5 percent are of the opinion that bank employees are unfriendly in their interactions. 8.5 percent of the respondents however said their interactions with bank employees appear distant and aloof. The implication of this result is that almost two-thirds of the respondents are not pleased with the interaction attitude of bank employees. The percentage of the respondents who gave a positive response is just slightly higher than the negative responses, and this is not commendable for organizations who desire to build sustainable relationships with their customers.

Customers' Assessment of the Impact of Interpersonal Communication on the Relationship

This section obtains customers' views on how interpersonal communication has affected their relationships with their banks. The result is presented in figures 14 and 15 below.

Figure 13

Effect of one-on-one Interaction on Customer Relationship

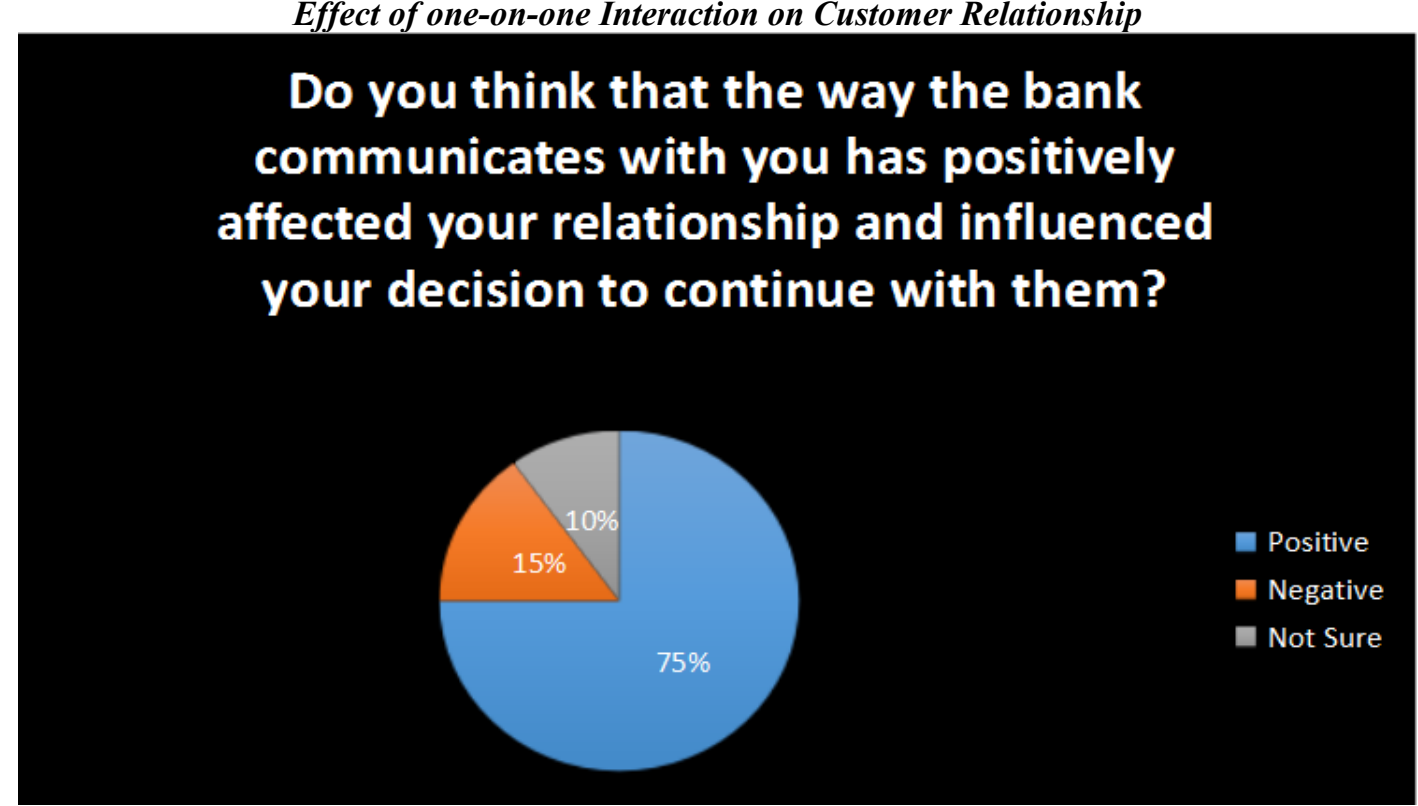

Figure 13 above shows that majority (75\%) of the respondents affirmed that personal interaction, whether by phone or face to face communication, has positively affected their relationship with their banks and influenced their decision to continue with them. While 15 percent did not agree with that, 10 percent did not have any opinion about that. 


\section{Analyses of In-depth Interview}

In this section, an analysis of data from the qualitative instrument used in this work is presented through the thematic approach. According to Braun and Clarke (2006):

The qualitative design focused on identifying factors that influence relationship management generally as a concept, and specifically interpersonal communication as a communication strategy for managing relationships between banks and their customers.

An in-depth interview was used to add depth and perspective to the research questions. The interview was conducted among the very senior bank employees who engage in relationship management through daily interaction with the customers in the selected bank branches. This included branch service managers, head of operations or customer service officers who open and manage the accounts, and the marketing or relationship managers who go out daily to canvas for new customers as well as get more businesses from the existing ones. These interviews were meant to elicit responses on the employees' knowledge of the relationship management concept as practiced in their banks. The in depth interview allowed the interviewer to probe and have control over the discussion with the bank employees in order to ensure that it remained within the boundaries of the discussion.

Major themes that characterize relationship management practice and communication in banks were identified. The issues covered in the interview centered on the five research questions formulated for this study in order to add depth and perspective to the questions, and they include:

- Bank employees' perception of relationship management, and strategies employed by banks in maintaining relationships.

- Communication strategies put in place by banks in order to achieve relationship management goals, as well as the communication patterns in these banks.

- The relevance of interpersonal communication in banks' business relationships as well as the interpersonal communication patterns in use by banks in relationship management.

- The role of relationship management in the achievement of banks' organizational objectives.

- The quality of interaction among the employees was assessed in order to determine whether healthy communication among the employees positively affected their interaction with customers in relationship building and maintenance.

- The impact of interpersonal communication, both verbal and nonverbal on the achievement of relationship management goals.

A total of fifteen interviewees were used for the sample selected from each of the 15 bank branches earlier selected for the sampling.

Table 11 below displays the sample size for the in-depth interview.

\section{Table 10:}

Sample Size for the In-depth Interview

\begin{tabular}{|l|l|l|l|l|}
\hline S/NO & \multicolumn{1}{|c|}{ BANK } & BANK CATEGORY & \multicolumn{1}{|c|}{ LOCATION } & SEX \\
\hline 1 & Access Bank Plc. & New Generation & Afikpo, Ebonyi State & M \\
\hline 2 & Diamond Bank Plc. & New Generation & Awka, Anambra State & M \\
\hline 3 & Eco Bank Nig. Ltd. & New Generation & New Generation & M \\
\hline 4 & Enterprise Bank Nig. Plc. & New Generation & Enugu, Enugu State & M \\
\hline 5 & Fidelity bank Plc. & New Generation & Abakaliki, Ebonyi & F \\
\hline 6 & First Bank Nigeria Ltd. & Old Generation & Aba, Abia State & F \\
\hline 7 & First City Monument Bank Plc. & New Generation & Nnewi, Anambra & M \\
\hline 8 & GTBank Ltd. & New Generation & Aba, ASbia State & F \\
\hline 9 & Key Stone bank Nig. Plc. & New Generation & Owerri, Imo State & M \\
\hline 10 & Main Street Bank Plc. & Old Generation & Enugu, Enugu State & F \\
\hline 11 & Sterling Bank Nig. Plc. & New Generation & Owerri, Imo State & M \\
\hline 12 & Union Bank Nigeria Plc. & Old Generation & Onitsha, Anambrs State & M \\
\hline 13 & United Bank for Africa Plc. & Old Generation & Abakaliki, Ebonyi State & F \\
\hline 14 & Unity Bank Nig. Plc. & New Generation & Enugu, Enugu State & M \\
\hline 15 & Zenith Bank Nig. Plc. & New Generation & Umuahia, Abia State & F \\
\hline
\end{tabular}

Source: Field Work 2015

The interviewees consisted of nine males and six females. Four of the males were relationship managers, three were service or operations managers, while two were heads of customer care departments. Similarly, three of the females were relationship managers; two were operations managers, while one was a customer service head. It was observed that bank employees are not permitted by their managements to grant interviews to the public and for this reason their names are with-held. All the names quoted here therefore are pseudo names. However, their age range fall between 29 and 35 years for the new generation banks interviewees, and 29 and 50 
years for the old generation banks interviewees.

Subsequently, the themes are discussed below, starting from an examination of bank employees' perception of relationship management to the contribution of interpersonal communication to the achievement of relationship management goals, as already enumerated above.

\section{Some Bank Employees' Perception of Relationship Management and Strategies Employed by Banks in Maintaining Relationships}

The in-depth interview revealed that all the banks have what they refer to as 'relationship managers' or account officers, who are the marketers. The existence of these relationship managers indicates that the concept of relationship management already exist in the banks. However, the researcher while interviewing the sample observed that most of the interviewees, especially those outside the department of marketing were not familiar with the term, as they quickly referred us to the relationship managers, explain that these are the ones responsible for relationship management, and that they themselves do not know much about the concept. From their responses on their perception of relationship management, we observed that most of them had been engaging in relationship management, albeit ignorantly. A good number of them did not appear to exactly understand what relationship management as a concept is about. When we explained in detail that we meant all the efforts they were making to ensure that they build and nurture a good relationship with their customers so that they could continue to patronize their banks, they then began to show interest. As we started posing our questions, they found out that they had been involved in nurturing relationships with their customers, but without attaching a name to the practice. This seems to suggest that they had been engaging in some of those activities without actually being conscious that what they were practicing was relationship management. However, they later affirmed that building and maintaining long term client/business relationships is the key to winning customer retention and loyalty. The excerpts from the following interviewees corroborate this perception:

Union Bank (M) Onyekachi:

You may need to come back later. The relationship manager who can take your questions on relationship management went out for marketing. Ah, okay, I see.

Before now, we had no business with cultivating customers. They came on their own. Today, the story is different. We have paid the price for neglecting customers, and we no know better. We go marketing for customers and looking for what to do to please them (2015).

First Bank (F) Obiageli:

The business manager is really the one involved in relationship management, but I can take your question. Go ahead. Well, First Bank, just like some other older generation banks seems to have come to grips with the fact that it is no more business as usual with the customers. Customers have realized that they have a choice. The bank is now making efforts to put the customer first in all they do and to see relationship from the customers' point of view (2015).

Our interview revealed that the new generation banks employees appeared to understand more what it means to establish and nurture relationships than the old generation banks, except for First bank and UBA who seemed to have against all odds transformed themselves into modern banks. Of course, it should be recalled that the emergence of the new generation banks heralded the introduction of new wave banking practice in Nigeria, which has relationship management as its top priority, even though, still among their employees, only the marketers and business managers appreciated the topic of our discussion. However, it is likely that employees at the branches may not be aware of the full implications of the relationship management concept, but top level managements may have it as a strategy for managing relationships.

The interviewees from GTB, Access, Zenith, Sterling Bank, FCMB, and Fidelity banks all affirmed that the customer is recognized as an indispensable partner to the business of the bank, and so all efforts are geared towards satisfying him even at high costs. The response from Union Bank, Unity Bank, key Stone Bank Mainstream Bank and UBA were not at variance with these assertions. As expected, it was observed from the discourse with the new generation bank interviewees that relationship management appears to be a norm in their banks, while some of the old generation banks appear to just be starting the practice.

In response to the question on relationship management strategies employed by their banks and what they think are the critical success factors in implementing the concept, Ezinne from Zenith (female) answered, "service quality culture, skilled and trained staff, communication - the need for modern information systems tops our list of preferences." She explained that for customers to be happy and keep patronizing a bank, the service delivery must be excellent, the staff must be well trained and knowledgeable, and of course the bank must invest in communication and information technology to complement the efforts of the employees in serving the customers better.

A GTB female interviewee (Nneka), corroborated this by indicating that she "preferred employee 
commitment and development, personalized and balanced communication (two way communication), and use of data base technology or customer-based information system". Employee commitment refers to the commitment of the employees to keeping the service promises made to the customers by the bank, and this she said is enhanced by management taking steps to develop the skills of its employees and improve their work attitude. When employees are skilled on and totally committed to their jobs, she explained further, they serve the customers better, and this makes for an improved relationship.

The interviewees from the other banks identified trust, product quality, service excellence, and employee attitude as strong determinants of relationship management success. Employee attitude to customers in course of serving them, they said is an important factor in relationships, as this is capable of affecting customer relationships either positively or negatively.

Zenith Bank, GT Bank and First Bank all indicated that they developed products for the high net-worth customers called premium cards. These are personalized cards that guarantee instant attention to the bearer in any branch of the bank that the customer enters. It was observed that ATM cards are also personalized by some of the banks like GTBank and Firstbank for some categories of customers and these bear the desired photographs and names of the account holder or holders where the account is a joint account. All these are relationship management strategies expectedly geared towards enhancing relationships and increasing customer retention and loyalty.

All the interviewees also unanimously confirmed that they are involved in socialization and bonding activities with their customers as a strategy to sustain their relationships with them. According to them, banks make it a point of duty to attend customers' social functions like burial ceremonies, birthday and wedding celebrations, as well as send cards and gifts during festive seasons to most of their customers. Every account officer, they all said ensures to visit the customers on regular basis in order to keep the relationship very strong and cordial. Cousins et al (2006, p. 854) support this, as they submitted that, informal processes create interpersonal linkages that stimulate the formation of trust and respect between individuals within the relationship. Again, Lawson et al (2007, p. 4) statement that, "off-site workshops, away days, social events and communication guidelines allow individuals the time and opportunity to strengthen and broaden the relationships at an inter-personal level", lends even more support to this practice.

Others affirmed that they are also learning to smile to customers and accord them a great deal of respect while serving them, as a strategy to maintain a good relationship with them.

From this discourse there appears to be a shift from transaction banking to relationship banking in both the old and new generation banks. In transactional banking, banks were only interested in maximizing profit through exchanging their offerings for the customers' money and so behaved passively with their customers. In contrast, the relationship era sees banking policies including customer interests, and maintaining good relationships with them. Bank managements have therefore put in place several relationship management techniques like effective communication, personal interaction involving politeness and smiles, service excellence and product quality, skilled and trained staff, data based customer information system, trust, commitment, service loyalty, socialization and bonding, and employee attitude, all aimed at improving relationships with their customers. These techniques are what Dindia \& Canary (1993) referred to as 'relational maintenance strategies', and the above position is in agreement with Kim's (2003) assertion that 'relationship management has become a key aspect of most firms' business strategy, prompting extensive deployment of customer relationship management systems'. The existence of these techniques was confirmed by the quantitative survey.

However, it was observed that Union Bank appears to be trailing back in relationship management, as the male employee interviewed confessed that the bank is just beginning to re-strategize in order to catch up with the present wind of relational banking that is sweeping through Nigerian banks. He explained that the bank is presently recruiting experienced staff from other banks to drive the new concept of service excellence in order to keep their customers from defecting, while recalling those lost to competition.

Nneka, GT Bank in response to whether relationship management has contributed to the achievement of his bank's organizational objectives explained that the most rewarding of the bank's relationship management techniques is service excellence. She said that the bank "delivers prompt and excellent service and treats our customers with respect and dignity", a claim to which according to him, their customers usually testify during external surveys on service quality and customer satisfaction. "We are always ranked 'first' in service excellence and customer satisfaction indices by international consultants. Our customers are already recommending the bank to their friends and relations", he concluded.

All the 15 interviewees affirmed also that bonding and socialization as a relationship management strategy has resulted in very strong bank-customer relationships, and they said that this has translated to individual customer loyalty to the banks. Attaching relationship managers to customers' accounts, they unanimously affirmed, strengthens the relationship leading to intimacy between the relationship officers and the customers. This is in agreement with Ahiazu, et al (2010), who found out that that there is a relationship that exists between the operators i.e. the accounts officer (Marketer) and the customer on one hand, and the bank and the customer 
on the other". The strength of this relationship they continued, affects business performance, having observed that the relationship between customers and account officers (marketers) appear to be even stronger than that between the bank and the customer, and could last for a life time.

This interview section agrees with the quantitative survey result, where the respondents rated their relationship with the banks as high and very high.

\section{Discussion of Findings}

This study employed more than one research design; therefore the findings will cover the two designs qualitative and quantitative research designs.

\section{Findings from the Quantitative Data}

The study found that:

- In the preliminary analysis of data, 68 percent of the respondents were males while 31 percent were females.

- 88 percent of the respondents were between 18 and 65 years of age, while 12 percent were above 65 years.

- 90 percent of the females were between the age brackets of 18 and 45 , while only 10 percent were 46 years and above; and that whereas 70 percent of the males were between 18 and 45 years, 30 percent were 46 years and above.

- $\quad$ Respondents consisted of 76 percent of the customers of the new generation banks, while the remaining 26 percent were customers of the old generation banks.

- The new generation banks had a greater share of the young and middle aged customers, while the old generation banks customers were made up of the more elderly in the society.

- The occupational distribution of the respondents showed that 38.75 percent were engaged general trading, $25.5 \%$ were in the education sector, students inclusive, 10.25 percent were industrialists, 8.75 percent were in the medical profession, seven percent were other civil servants, 5.25 percent were artisans and other professionals, and lastly 4.45 belonged to the engineering profession. This corroborates with the nature of the research area. Although South East is known to be a region of the elites and civil servants, majority of the males are known to be business inclined, and so do not give themselves to much learning. The findings therefore represent the business oriented nature of the region.

- Bank customers have access to many communication strategies in their relationship with the banks. These include: interpersonal communication (one-on-one interaction, group discussion, telephone, SMS), the Internet (e-mails, etc.), letters, mass media (radio, television, newspapers), and social media (WHATSAPP, Facebook, You Tube, Twitter), notices, suggestion boxes, and signage.

- Interpersonal communication occupies a very important place in relationship management and that the level of participation in interpersonal communication in Nigerian banks is very high. It was discovered to be the most popularly used and most preferred by customers, and that 88 percent of customeremployee interaction is one-on-one.

- The different relationship management techniques contributed immensely to banks' organizational objectives by assisting the banks to develop and nurture sustainable relationships with their customers and that bank customers have very cordial relationships with their banks. The concept has earned the trust of customers on the banks.

- Interpersonal communication positively influenced the achievement of relationship management goals, by enhancing bank-customer relationships.

- Internet and social media participation was very low.

- Many IPC patterns are used by banks to communicate with their customers, and that the most preferred is the one-on-one interaction, while the least popular is group discussion.

- The interaction attitude of employees from the new generation banks is slightly better than that of the old generation bank employees.

- Bank customers are apprehensive of the non-verbal communication cues consciously or otherwise displayed by bank employees during interaction, and are also either positively or negatively influenced by them, depending on individual perception of these non-verbal display.

\section{Findings from the Qualitative Data}

Findings from the qualitative data revealed that:

- Relationship management is still an emerging concept in Nigerian banks.

- Although employees of most of the banks were practicing relationship management, it is not widely known among bank employees as a dominant management concept because relationship marketing was 
more popular with the bank marketers. Research assistants, even in some of the new generation banks, were referred to the relationship managers or account officers once the term relationship management was mentioned.

- Communication is at the centre of relationship building and nurturing.

- Banks have put in place a variety of communication strategies, to ensure the success of the relationship management orientation, but in different degrees. Some are dominant while others are dormant.. These include: interpersonal communication (one-on-one interaction, group discussion, telephone, SMS), the Internet (e-mails, etc.), letters, mass media (radio, television, newspapers), and social media (WHATSAPP, face book, You Tube, Twitter), notices, suggestion boxes, signage, opinion meters, bill boards, and bulletins.

- Interpersonal communication is the prevalent communication strategy used by banks to interact with their customers in their day to day business.

- Most bank managements have created a favorable interpersonal communication climate in order to facilitate relational well-being among the employees. The relationship maintenance strategies of sharing positiveness or remaining cheerful, demonstrating openness or direct discussion and disclosure, being polite or courteous (Stanford and Canary (1997) are consciously being employed by most bank employees in their day to day interaction with each other, in order to help improve their relationship with the customers.

- While banks use SMS often to communicate to customers, like alerts, through phone and ATMs, customers do not acknowledge it as a communication channel because it does not require instant feedback most of the time. Even in a few cases where they could have responded instantly, they still would rush to the bank to confirm that the message was genuine.

- $\quad$ There is a variance between the viewpoints of banking clients and bank employees. It was observed that bank employees rated the quality of their relationship with, as well as their interactive attitude to the customers more highly than did the customers. This is an indication that they do not fully understand their customers' emotions.

As confirmed by the in-depth interview, the use of interpersonal communication affords the customers the benefit of enjoying the absence of ambiguity and air of informality in their interactions with the employees, and this bank employees say, makes for better understanding and closeness in the relationship. Instant feedback was identified as a key requirement of most banking transactions and also one of the benefits that the customers derive from the use of interpersonal communication.

Non-verbal communication was found to play a very important role in banks' communication with their customers. Gestures, postures, signs or emotions and body language each are interpreted differently by individual customers with different dispositions. Negative displays of nonverbal communication like frowning were found to affect customers' emotions negatively, just like positive ones like smiles had very positive effects on them and improved the relationship. Even the ambience of the banks - the buildings, cozy environments like neat, well-lit and cool banking halls as well as staff dressing attract and appeal to customers who patronize the banks. The logos and colors of the different banks speak for themselves. One of the most instantly recognizable elements of a corporate visual identity is colour and it promotes a strong non-verbal message on the companies' behalf (Balmer and Gray, 2000). Customers can identify their bankers from afar by the colour of their professional dressing. It was observed that seats have disappeared from banking halls of many bank branches. This signifies prompt service and communicates to the customer that his time is of essence to bank.

\section{Summary}

This study was conducted to assess how Nigerian banks use interpersonal communication to achieve relationship management goals, which entails building and sustaining strong relationships between the banks and their various customers. The study used selected banks in South Eastern Nigerian as a case study. The results of the study would form significant contributions to the very limited references on establishment and management of relationships in service organizations in Nigeria, especially banks.

\section{Findings}

The findings demonstrated that 68 percent of the respondents were male, while 31 percent were females, thus signifying a considerable margin between the genders used in the study, which tilted in favour of the males. Again, 16 percent of the respondents were youths, 72 percent were middle aged, while 12 percent were the elderly. A cross tabulation analysis between age and gender showed that the females were both fewer in number and younger in age. The survey had more females in the middle age - 70 percent, as against 50 percent among the males. 20 percent of both sexes were in the youthful age. Put together, 90 percent of the females were between 18 and 45 years, while only 70 percent of the men fell within this age bracket, whereas, the males topped the chart in the elderly age bracket, with 30 percent, against 10 percent of females. 
The study reveals a preponderance of young people as customers of the new generation banks while the customers of the old generation banks consisted more of the elderly in the society.

It was also discovered that more than one-third (38.75\%) of the respondents were engaged in all kinds of trading or general merchandise. About a quarter $(25.5 \%)$ was in the educational sector, students inclusive. Professionals accounted for 13.20 percent, while 10.25 percent consisted of industrialists. Seven percent were other civil servants like local government workers, the police among others, while those engaged in other businesses like artisans, transporters and others accounted for 5.25 percent. The last slot of 4.25 was taken by industrialists.

Findings from the study again revealed that 49 percent of the respondents had been in banking business for five to ten years, and 27 percent for above ten years. 24 percent were new entrants in banking business. A chisquare test revealed a relationship that shows that age is a determinant of the length of customers' banking relationship. The older respondents were found to have maintained banking relationships for longer periods than younger ones.

The study revealed that banks had put in place a lot of relationship management strategies, including communication, to ensure strong and sustainable relationships with their customers. The results also show that these strategies have yielded positive results. Customers were found to have very cordial relationships with their banks.

The study also found a high level of participation in interpersonal communication, both verbal and nonverbal between banks and their customers. This consisted of mainly one-on-one interaction, with a very low level of group discussions. Interpersonal communication was found to be generally very convenient for the customers, who usually preferred to walk into the bank and do their business one-on-one, probably due to the nature of banking transactions. It was found to be the dominant; most frequently used and most preferred communication strategy by both banks and their customers. Interpersonal communication was found to have enhanced greatly bank-customer relationships.

The customers were found to interpret non-verbal communication cues differently and this affected their relationships with the banks according to individual dispositions. For some, these made them feel relevant but for others negative non-verbal displays made them feel irrelevant or a nuisance.

The results from the in-depth interview revealed that bank employees are aware that it is important for the banks to build and maintain good relationships with their customers but there appeared to be no formal awareness of the concept of relationship management. Equally, they had a lot of trainings on effective communication skills but seemed not to relate them to the relationship management concept. It was only the marketers or account officers who appeared to understand better what managing relationships was all about, because they were relationship managers who were involved in relationship marketing, and went about scouting for customers.

\section{Conclusion}

The key conclusion from the findings of this study is that interpersonal communication occupies an important place in relationship management in Nigerian banks and that it is the dominant, most popularly used and most preferred communication strategy by both banks and their customers. The use of interpersonal communication by banks has fostered good relationships between banks and their customers, and is still improving. This supports the fact that relationship management goals have been achieved in Nigerian banks, since their customers confirm that they are ready to partner with them in selling their brands.

The result of this research has implications for bank employees also. Some still appear rude and unfriendly in their relationship with customers, although the quality of customer employee interaction was high. A good number of bank customers saw the employees as rude in their interactions. However, the in-depth interview revealed that a lot of work is being done by bank managements in the area of communication and attitude to improve the quality of employee-customer communication. There are on-going campaigns in banks on good interpersonal relationship through good interaction among staff, with sanctions on violation of the laid down rules of communication within the banks. This is expected to generate healthy interaction among bank employees that would impact positively on their interaction with the customers. This is to avert the warning of West \& turner (2000), that incompetent communicators may not be able to develop relationships.

\section{Recommendations}

Based on the major findings of this study, the following recommendations are therefore put forward:

1. Banks should cascade the awareness about the importance of the relationship management concept to all employees as well as departments, instead of concentrating at the top management level, with a low level of participation by marketers or relationship managers. The study shows that the service personnel at the different touch points or service outlets who appear completely or partially ignorant of the relationship management concept are actually the ones who interface with the majority of bank 
customers, as opposed to the marketing units who serve as account officers to the blue-cheap customers who form only a minimal percentage of the entire customer population. This is in support of Adeyemi's (2013) assertion that relationship management is not just for few departments but is a fundamental business strategy that should be carried out within the whole organization, spanning different business functions.

2. Bank managements should accord interpersonal communication the importance it deserves in achieving relationship management goals, given the relationship level and the present nature of banking transaction. Although bank employees interact daily on on-on-one basis with customers, they seem to be oblivious of its implications on the relationship; otherwise the high level of rudeness among bank employees would not have been recorded. Greater importance seems to be accorded to service excellence by the employees, without appreciating the fact that service is rendered through employeecustomer interactions.

3. Banks should clearly define public relations functions, instead of fusing them with the marketing and corporate communication duties. That will enable the PR personal to drive down the concept of relationship management, while interpersonal relationship will be clearly separated from brand acceptance or image laundry.

4. The old generation banks need to work on the attitude of their employees to their customers to enable them learn how to manage the customers better in order to reap the benefits of word-of-mouth from them.

5. The level of participation in group discussions with the customers should be enhanced by bank managements in order to reap its full benefits for a more fruitful relational maintenance.

6. The old generation banks should review their relationship management strategies with a view to tailoring them more to the younger generation of customers for the purpose of continuity. They seem to have a preponderance of old customers, contrary to what obtains in the new generation banks.

7. Finally, bank managements should endeavor to create more on-line relationships to enable them continue to be relevant in this evolving era of digital communication in Nigeria. As Waddington (2013) pointed out, 'the context in which an organization can thrive is rapidly moving from its ability to create traditional relationships with publics to its ability to do this in an on-line world, and mostly via third parties that are beyond its control'.

\section{Suggestions for Further Research}

Research in relationship management and communication, especially interpersonal is still relatively new with regards to the Nigerian experience. Future research could examine many different areas, based on the findings of this study.

The few studies available for review on relationship management in Nigeria covered mainly banks, insurance companies, and the communication industries. Another area of study could be to extend the research on relationship management to other service organizations like the airways, the police, hospitals and hospitality industries. These are organizations that render service to humanity and so need to be apprehensive of their relationships with the people they serve.

This research though carried out on the communication component of relationship management, focused on interpersonal communication only. Research could also be carried out on the social media and on-line communication to assess the extent of participation in these communication patterns by banks and their customers, as well as its contribution to relationship maintenance and sustenance in service organizations.

We suggest a more detailed research to ascertain the tangible contribution of communication and relationship management to the achievement of organizational objectives in terms of financial profit.

Research could also be carried out extensively on the management of relationships between organizations and their internal customers, the employees, and how internal communication in banks affects bank-customer relationships. A full study could be done on the implications of nonverbal communication on organizationpublic-relationship.

Fees and charges/returns on investment are relationship management components. Future research could still be conducted to determine whether regular and arbitrary increase in charges, fees and commissions can reduce or terminate relationships in Nigerian banks and other service organizations who engage in relationship management. Similarly, the study could investigate the effect of good returns on investment like dividend warrants or interest on savings or fixed deposits on the relationship.

The relationship between the level of technological deployment in organizations and organizations-publicrelationship (OPR) can also be investigated. This includes IT (information technology) infrastructure

\section{REFERENCES}

Adeyemi, K.S. (2007). Banking sector consolidation in Nigeria: Issues and challenges. Retrieved from: 
www.cenbank.org/out/.../Banking\%20Reforms\%20Get\%20Boost.pdf January 20, 2012.

Adedeye, Tolulope Charles (2013). Impact of customer relationship management on perceived bank performance in Oyo Town, Nigeria. International Business and Management, 6 (2), 137-146. available from: http://www.cscanada.net/index. Retrieved 1/12/2014.

Ahiauzu, A.I. (2006). Advanced research methods in the management sciences; Port Harcourt. Lecture notes $\mathrm{PhD}$ class. Rivers State University of Science and Technology. Retrieved from: http://www.europeanjournalofsocialsciences.com

Ayopo O. O., Darego W. M, \& Opara, B. C. (2010 September), “An empirical study of relation ship marketing orientation and bank performance" Research Journal of International Studies, Issue 16, 47. Retrieved from: http://www.europeanjournalofsocialsciences.com

Balmer, J. M. T. \& Gray, E. R. (2000). Corporate identity and corporate communication: Creating a competitive advantage. Industrial and Commercial Training, 32(7), 256

Berger, C. R. \& Bradac, J.. J. (1982). Language and social knowledge: Uncertainty in interpersonal relations. E. Arnold, p. 7.

Boeder, P. (2002). Non-Profits on e: How non-profit organizations are using the internet for communication, fundraising and community building. First Monday, 7, 7. Retrieved June 10, 2009 from: http://www.uic.edu/htbin/cgiwrap/bin/ojs/index.php/ fm/article/view/969/890

Boone, M.E. (2001), "Managing interactively: Executing business strategy improving communication\& creating a knowledge sharing culture". In Hybels, Sandra, \&Weaver II. New York, NY: McGraw-Hill, Inc.

Bosch, J.K., Tait, M. \& Venter, E. (2006), "Business management: An entrepreneurial perspective" Port Elizabeth: Lectern Publishing.

Bruning, S. D. \& Ledingham, J. A. (1999). Relationships between organizations and publics: Development of a multi-dimensional organization-public relationship scale. Public Relations Review, 25, 157-170.

Burleson, B. R., Melts, S. and Kirch, M. W. (2000). Communication in close relationships. A source book eds., Hendrick, C. and Hendrick, S. S. thousand Oaks, CA, Sage,

Burns, R.B. \& Burns, R.A (2008), "Business research methods and statistics using SPSS" London: Publications.

Cherry, K. (2015). What is cognitive dissonance? Retrieved from www.psychology.about.com

Cheng-Ter, K. \& Chang, C. (2011). The study on the antecedents of relationship quality and loyalty of Urban Business Club: Landmark Club.

Crosby, L., Evans, K., and Cowless, D. (1990). "Relationship quality in services selling; An interpersonal influence perspective", Journal of Marketing, 54 (3), 68-81

Dahlgren, P. (2009). Media and political engagement: Citizens communication and democracy. Cambridge: Cambridge University Press.

Danton, M. Aylor, B. (2001). A relational uncertainty analysis of jealousy, trust, and maintenance in longdistance versus geographical close relationships. Communication Quarterly, 49, 172-189.

David, P. (2004). Extending symmetry: Toward a convergence of professionalism, practice and pragmatics in public relations. Journal of Public relations Research, 16(2), 185-211.

Douglas, W. (1990). Uncertainty in information-seeking and liking during initial interactions. Western Journal of Speech Communication, 54, 66-81.

Dunu, I. V., Ugbo, G. O., Ezepue E. (2015). Displacement or complementary effect: An assessment of traditional and new media use patterns among elites in south-east Nigeria. Higher Education of Social Sciences, 8(4), 8-18. Available from: http//www.cscanada.net/index.php/hess/aticle/view/6849.

Evans, J.R. and Larkin R.L. (1994), “The Relationship marketing process: A conceptualization and application”. Industrial Marketing Management 23, 438-452

Fagbemi, A. O. \& Olowokudejo, F. F. (2011). A comparison of the customer relationship management Strategies of Nigerian banks and insurance companies. Journal for Business Research, 1 (3), 161-170

Greenberg ., \& Baron, R. A. (2000). Behavior in organizations. $7^{\text {th }}$ edition. Upper Saddle River, NJ: PrenticeHall.

Gregory, A. (2009). Management and organization of public relations. In Ralph Trench and Liz Yeomans, (ed.) Exploring Public Relations, London: Pearson Education Limited, 19-34

Gregory, A. (2006a). Management and organization of public relations. In Trench, R \& Yeomans, L. (eds.). Exploring Public Relations, London, Pearson Education Limited,

Gremier, D. D \& Gwinner, K.P. (2000), "Customer-Employee Rapport in Service Relationships" Journal of Service Research, August, 3 (1), 82-105..

Gronross, C. (2000), "Service management and marketing: A customer relationship management approach ( $2^{\text {nd }}$ ed.), Wiley Chic ester.

Grunig, J. E., \& Hunt, T. (1984). Managing public relations. New York, NY: CBS College Publishing

Grunig, J. E., \& Huang, Y. (2000). From organizational effectiveness to relationship indicators: Antecedents of relationships, public relations strategies and relationship outcomes. In J. A. Legingham\& S.D. Bruning 
(Eds.), Public relations as relationship management: A relational approach to the study and practice of public relations (pp. 23-54).

Grunig, J. E., \& Hunt, T. (2000).Direction de relaciones publicas. Barcelona, Spain: Gestion 2000. (Spanish translation of Managing public relations.)

Grunig, J. E. (2001). Two-way symmetrical public relations: Past, Present and Future. In: Robert L. Heath, (Ed). Handbook of Public Relations, London: Saga Publications, pp 11- 30.

Grunig, J. E. (2006). Comments on communication management: Researching corporate Communication and knowledge communication in organizational settings. Studies in Communication Sciences (University of Lugano, Switzerland), 6(2). 1-4.

Grunig, J. E. (2008). Excellence Theory in Public Relations. In W. Donsbach (Ed.), The International Encyclopedia of Communications, 4 1620-1622, Oxford, UK.\& Malden, MA; Willey Blackwell Retrieved from: http://kdpaine.blogs.com/files/encyclopedia (May 31, 2014).

Grunig, J. E. (2009). Paradigms of global public relations in an age of digitalization, Prism Journal 6(2) p.3. retrieved from; http://praxis.massegacnz/prismonlinejourn.html

Grunig, L. A., Grunig, J. E., \& Dozier D. M. (2002). Excellent public relations and effective Organizations: a study of communication management in three countries. Mahwah, NJ: Lawrence Erlbaum Associates

Gwin, C. E. (2009). The impact of trust and branc relationship quality on perceived value and loyalty in consumer goods environment.2009 SWDSI proceedings, 528-537

Hartley, P. (1999). Interpersonal Communication. Routledge, London.

Hogg, M. and Vaughan, G. (2005). Social Psychology, $4^{\text {th }}$ ed. London: Prentice Hall.

Huang, Y. H. (1997). Public relations strategies, relational outcomes, and conflict management Strategies. Unpublished doctoral dissertation, University of Maryland, College Park.

Hybels, S. \& Weaver II, R. L. (2004), “Communicating effectively" (6 ${ }^{\text {th }}$ ed.)New York, NY: The McGraw-Hill Cos, Inc.

Jensen, K. B. (1991). "Introduction: The qualitative turn" in K. B. Jensen \& N. W. Jankowski (eds). A handbook of qualitative methodologies for mass communication research. Routledge, London, 17-43.

Jones, R. G. Jr. (2007). Drag queens, drama queens and friends: Drama and performance as a solidarity building function in a gay male friendship circle, Kaleidoscope. A Graduate Journal of Qualitative Research,2007, $p$. 61-84.

Karten, N. (2002). Communication gaps and how to close them. New York: NY. Dorset House. Retrieved from www.ayeconfrence.com

Keller man, K. \& Reynolds, R. (1990). When ignorance is bliss: The role of motivation to reduce uncertainty in uncertainty reduction theory. Human Communication Research, 17, 5-35.

Kent, M. L. \& Taylor, M. (2002). Building towards a dialogic theory of public relations. Public Relations Review, 28(1), 321-334.

Kent, M. L. \& Taylor, M., \& White, W. J. (2003). The relationship between website design and organizational responsiveness to stakeholders. Public Relations Review, 29(1), 63-77.

Kim, J. et al. (2003). A model for evaluating the effectiveness of CRM using the balanced score Card. Journal of Interactive Marketing, 17(2), 5-19.

Kotler, P., Armstrong, G., \& Tait, M. (2010). Principles of Marketing; Global and Southern African Perspectives. Cape Town; Pearson Education.

Kotler, P. \& Armstrong, G. (2001), "Principles of marketing” 9th International edition. Upper Saddle River, N.J: Prentice-Hall

Lages, C., Lages C. R. \& Lages L.F.(2005). The RELQUAL scale: A measure of relationship quality in export market ventures. Journal of Business Research, 58, 1040-1048.

Laskin, A. V. (2009). The evolution of models of public relations: An outsider's perspective. Journal of Communication Management. 13 (1), 37-54

Leavitt, H.J. \& Muller R. A. H. (1951) some effects of feedback on communication. Human Relations, 4, 401410. In: Ramesh Aryal (2012). Retrieved from

rameshtalks.wordpress.com/tag/role-of-feedback-in-communication.

Ledingham, J. A. (2003). Explicating relationship management as a general theory of public relations. Journal of Public relations research, 15(2), 181-198

Ledingham, J. A. \&Bruning, S. D. (2000). Public relations as relationship management: Arelational approach to the study and practice of public relations. Mahwah, NJ: Lawrence Erlbaum Associates, Inc.

Ledingham, J. A., \& Bruning, S. D. (2000). A longitudinal study of organization-public- relationship dimensions: Defining the role of communication in the practice of relationship management. Mahwah, NJ: Lawrence Erlbaum Associates, Inc.,

Lee Edward (2009a). Public relations theories: An overview. In: Ralph Tench and Liz Yeomans, (Ed). Exploring public relations, 2009: Pearson Education Limited, 149-169. 
Lemo, T. (2005) Regulatory oversight and stakeholder protection", A paper presented at the BGL mergers and acquisitions interactive seminar, Eko Hotels \& Suites, V.I., Lagos June 24. Journal of Public Relations Research, 2003, 15(2), 181-198)

Mohegan, R. (2010). Closing the communication gap in your relationship. Retrieved from:http $\backslash$ www.therelationshipsuit.com

Morgan, R.M. \& Hunt, S.D. (1994), The commitment-trust theory of relationship marketing. Journal of Marketing, 58, 314-328.

Moreals, S. (2000). Survey of American Workers report communication as most important skill in Work Place. In Hybels, S., \& Weaver R. L. II, (2004), "Communicating effectively" (6 ${ }^{\text {th }}$ ed.) New York, NY: The McGraw-Hill Cos, Inc.

Ndubisi, N.O. and Chan, K.W. (2005). Factorial and discriminate analyses of the underpinnings of relationship marketing and customer satisfaction. International Bank Marketing, 23 No. 3: 542-57.

Ndubuisi, N. O. (2007). Relationship marketing and customer loyalty. Marketing Intelligence, 25(1), 98-106.

Nguyen, A., and Western, M. (2006). The complementary relationship between the Internet and traditional mass media: The case of online news and information. Information Research, 11(3), 1-18

Nwuneli O. (1991). Research strategies in population communication in Africa. Nairobi: Space Sellers Ltd.

O'Leary, Z. (2005). Researching real-world problems: A guide to methods of inquiry. London: Sage Publications.

Reichheld, F. and Sasser, W. (1990), Zero defects: Quality comes to services, Harvard Business Review, 68, 105-111.

Reichheld, F.F. (1996). Learning from customer defections. Harvard Business Review, 56-69. Research Journal of International Studies, (September, 2010) 16, 50

Rootman, C. (2010). International comparative study on the relationship marketing and consumer retail banks. Retrieved from: http://www.nmmu.ac.za/document/thesis/Chantal\%20Rootman.pdf

Rosenberg, L. J. \& Czepiel, J. A (1984). A marketing approach to customer retention. Journal of customer marketing, 1, 45-51

Russell, B. \& Purcell, J. (2009). Online research essentials designing and implementing research studies. San Francisco: Jossey-Bass.

Sekaran, U. (2000). Research methods for business: A skill-building approach ( $3^{\text {rd }}$ ed.). New York, NY: John Wiley and Sons.

Sethi, D. \& Seth, M. (2009). Interpersonal communication: Lifeblood of an organization. The IUP Journal of soft skills, 3, 4-5.

Sharp, B. \% \& Sharp, A. (1997). Loyalty programs and their on repeat-purchase loyalty patterns. International Journal of Research in Marketing, 145, 473-486.

Sin, L.Y.M., Tse, A.C.B., Yau, O.H.H.M. (2002) The effect of relationship marketing orientation on business performance in a service-oriented economy. .Journal of Services Marketing, 16 ( 7), 656-67.

Sorce, P. (September 2002). Relationship marketing strategy: An Exploratory study of consumer preference towards relationship marketing tactics: A research monograph of the printing industry center. New York, NY: John Wiley and Sons Publishers. Retrieved from: http://print.rit.edu/pubs/02 04 sorce.pdf

Stafford, L., \& Canary, D. J. (1991). Maintenance strategies and romantic relationship: Type, gender and relational characteristics. Journal of Social and personal Relationships, 8, 217-242.

Storsul T. (2014). "Delberation or self-presentation?: Young people, politics and social media". Nordicom Review. 35( 2), 17-28.

Thompson, P. \& Mchugh, D. (2002). Work organizations. New York, NY: Palgrave.

Thomslison, T. D. (2000). An interpersonal primer with implications for public relations. In J. A Ledingham \& S. D. Bruning (Eds.), Public relations as relationship management: A relational approach to the study and practice of public relations (pp, 177-204). Mahwah, NJ: Lawrence Erlbaum Associates.

Van Riel, C.B.M. \& Fombrun, C.J. (2007). Essentials of corporate communication. Abingdon: Routledge.

Vercic, D., Ruler, B., Bustchi, G., Flodin, B. (2001). The definition of PR: A European view. Public Relations Review, 27 (4), 373-387.http://www.scribd.com/doc/25357/On

\section{INTERNET SOURCES}

Nigerian Banking Report: retrieved 10.01.2012 from: http://www.cenbank.org/Supervision/Inst-DM.asp, retrieved January 10, 2012.

Banking Reforms (2010), Retrieved 10th January, 201 